\title{
Information Content of Aggregate and Individual Insider Trading
}

\author{
Dimitris Andriosopoulos $\uparrow$ and Hafiz Hoque*
}

\begin{abstract}
We examine the impact of aggregate insider trading on market returns in the UK. We find that, on aggregate, insiders are contrarians, but their trades are not informative, contrary to previous US evidence. We suggest that this discrepancy is related to the regulatory setting in the UK where insiders have to report their trades within six days. Then we analyse the shortrun market reaction to insider trades and find that the information content of insider trading is limited to the period surrounding the announcement dates. We show that market-to-book, company size, stock volatility and market volatility have a significant impact on reporting period returns. In addition, we find that the market reaction is much weaker after controlling $\mathrm{M} / \mathrm{B}$ and size. Finally, we show that insiders time in high volatile stocks, and following high market volatility.
\end{abstract}

Keywords: Insider trading, bull-bear market, information content, contrarian strategy, managerial timing.

JEL classification: G14, G39.

*Corresponding author: Tel.: +44(0) 751589 0949. Swansea University, Singleton Park, SA2 8PP, United Kingdom, e-mail: H.hoque@ swansea.ac.uk (H. Hoque)

$†$ Hull University Business School, Cottingham Road, Hull HU6 7RX, United Kingdom, email: d.andriosopoulos@hull.ac.uk (D. Andriosopoulos)

We thank Meziane Lasfer, Mario Levis, Ian Tonks and Giovanni Cespa for valuable comments. We thank participants of Advanced Corporate Finance Workshop, Aarhus, Denmark in spring 2008 and Jay Ritter for valuable comments. All remaining errors are our own responsibility. 


\section{Introduction}

Previous studies show that insiders are contrarians as they buy shares following a price decline and sell after a price run up. However, the extent to which such trades convey information is mixed. For example, Lakonishok and Lee (2001) find that insider trades are not informative in the short run. In contrast, Fidrmuc, Goergen, and Renneboog (2006) show that insider trades do convey information to the market as share prices increase (decrease), subsequently to their buy (sell) trades. The impact of aggregate insider trading on the market is examined in the existing literature. For example, Seyhun (1988) shows that net aggregate insider trading activity in a given month is significantly and positively correlated with the market return during the subsequent 2 months. Seyhun (1992) documents that for the period from 1975 to 1989 , the aggregate net number of open market purchases and sells by corporate insiders in their own firms predict up to 60 percent of the variation in one year ahead aggregate stock returns. Knewtson, Sias and Whidbee (2010) show that demand by aggregate insiders predicts time series variation in the value premiums. Lakonishok and Lee (2001) show that insiders in aggregate are contrarian traders but they have better predictive ability than simple contrarian strategies. Marin and Oliver (2008) investigate insider trading activity prior to crashes and find that insider purchases remain low all year long, but increase only one month prior to the share price jump. On the other hand, Fahlenbrach and Stultz (2011) find that bank CEOs did not reduce their shares holdings in anticipation of the crisis or during the crisis. As a result, they suffered extensive wealth losses in the wake of the crisis ${ }^{1}$.

However, the literature that investigates the impact of aggregate insider trading on market returns focuses in the US, and to the best of our knowledge, no study focuses in the UK. We consider the shortcomings and unresolved puzzles in the insider trading literature to explore further the information provided by the corporate insiders and relate it to the alternative information environment in which they trade. Insiders in the UK are more likely 
to possess superior information because they are limited to executive and non-executive directors. In contrast, in the US, the definition is much broader as officers, key employees and large shareholders are all considered as insiders. Moreover, the differences in insider trading regulations and in reporting periods ${ }^{2}$ between the UK and the US can provide additional insights.

This study contributes to the literature in several ways. First, this research investigates whether managers use market sentiment as a platform to act like contrarians. According to Seyhun (1988), insiders sell after significant stock price increases and buy after price declines. Similar results are documented for the aggregate insider trading (e.g., Seyhun (1992) and Lakonishok and Lee (2001)). In line with this, Jiang and Zaman (2010) assert that contrarian strategy implies insider trading as a reaction to market returns. We use market states to test the contrarian behaviour of insiders. If managers use the market platform to act like contrarians, their purchases are expected to dominate in bear periods, and their sell trades during bull periods. We define the bull market as January 1999 to March 2000 and January 2004 to December 2007 and bear period as April 2000 to December 2003. Furthermore, we test whether there is asymmetric price response of buy and sell trades in bull and bear periods.

Second, this study tests whether the insiders' view differs systematically from market valuations, and they try to take advantage of a potential misvaluation. Previous research on insider trading finds that insiders try to take advantage of perceived mispricing, suggesting market timing (Jenter (2005), Lakonishok and Lee (2001) and Rozeff and Zaman (1998)). There is evidence that insider trading is not random in value and glamour stocks (Rozeff and Zaman (1998), Lakonishok and Lee (2001) and Gregory, Tharyan and Tonks (forthcoming) ${ }^{3}$ ). They also show that contrarian strategies are useful in market timing. Recently, Knewtson, Sias and Whidbee (2010) show style timing by the insiders. We carry an out-of-sample test 
for managerial timing by corporate insiders and the information content of such trades under UK institutional setting where the trades are reported relatively quicker contrary to the US reporting regulations. Third, this study investigates whether insiders are actively involved in small companies, and whether their timing skill is confined to small companies.

Fourth, recent evidence shows that trading by insiders does not convey information after controlling for M/B and size (Jenter, 2005). Similarly, Lakonishok and Lee (2001) find that after controlling for $\mathrm{M} / \mathrm{B}$ and size, insider trades in most firms do not predict subsequent stock returns in the long run. This research tests whether insider trades in the UK are informative in the short run after controlling for size and M/B. Finally, we test whether information asymmetry as measured by stock and market volatility have an impact on the market reaction to insiders' trades as in Kyle (1985). We extend the previous literature by documenting timing in high volatility stocks and following a period of high market volatility.

Our results can be summarised as follows. We find that net purchase ratio (NPR) is positive (negative) in bear (bull) market, which implies that insiders purchase (sell) in the bear (bull) market. The conclusion holds after controlling for insiders' contrarian behaviour. In general, the aggregate insider trading is consistent with contrarian behaviour. However, the aggregate insider trading does not predict market returns. In addition, when we analyse individual trades, the behaviour and price response of insider trades is not asymmetric in bull and (bear) markets. Third, we find that the perceived mispricing, as measured by market-tobook ratio, affects significantly the market reaction to the trades in the short run. Fourth, Insider purchases convey additional information to the market, as this study finds economically and statistically significant returns around the announcement period. However, these returns vary with size, M/B, stock volatility and market volatility. The finding that most of the abnormal returns vary with $\mathrm{M} / \mathrm{B}$ and size is consistent with the view that insiders trade based on perceived mispricing and smaller companies. 
This paper proceeds as follows. Section 2 discusses existing literature, and sets up the hypothesis. Section 3 describes the data. In section 4, the relationship between market return and aggregate insider trading is analysed. Section 5 presents the results of the event period returns. Section 6 concludes.

\section{Related Literature and Hypothesis}

Previous research unanimously shows that insiders are contrarian traders. For example, Seyhun $(1986,1992)$ shows that insiders are more likely to sell (purchase) shares following periods of significant price appreciation (declines), consistent with insiders trading in anticipation of subsequent price reversals. Assuming that markets consist of two types of traders, informed and uninformed (noise), and stock prices are affected by the trading of both types of traders, then prices can move away from fundamental values (Shiller, 1984; De Long et al., 1990). It is possible that noise traders may drive market prices away from intrinsic values even in the absence of new information. Hence, a stock that was trading roughly at its intrinsic value could decline (rise) significantly because of such noise trading. Corporate insiders may then perceive the stock to be undervalued (overvalued) and buy (sell) it. Such a relationship would be viewed as insiders following a contrarian investment strategy. Brennan and Cao (1996) show that poorly informed agents are 'trend chasers', purchasing more risky security when its price rises and selling when price falls, while better informed agents acts like contrarians, selling on a price rise and buying on a fall. These arguments lead us to set up the following hypothesis.

Hypothesis 1: For individual trades as well as aggregate measure of insider trading, insiders are expected to buy (sell) after a significant decrease (increase) in price, and following the trade, there should be a price reversal. 
If the contrarian strategy is employed by insiders at the firm specific level then there should be no relation between market returns and insider trading. On the other hand, if "noise" trading is a market wide phenomenon then a relation between aggregate insider trading and market return should exist (Jiang and Zaman, 2010). In this case, market returns would predict insider trading behaviour. Chowdhury, Howe and Lin (1993) and Lakonishok and Lee (2001) provide evidence that aggregate insider trading is driven by the contrarian strategies. We test whether insider trading pattern is different across the bull and bear markets, i.e. whether insider buying is higher in bear market and insider selling is higher in bull market. If insiders use a market platform to act like contrarians, we expect them to buy in bear periods, and sell in bull periods, to reflect their expectations of price reversals. Therefore, we split our sample period into bull (01/1999 to $03 / 2000$ and $01 / 2004$ to $12 / 2007$ ) and bear $(04 / 2000$ to $12 / 2003)$ periods to assess the trading patterns of insiders ${ }^{4}$.

Hypothesis 2: There is no difference in buying (selling) in bear vs. bull period.

A related question would be whether there is any difference in the market reaction to insider trading in bull (bear) market. Chiyachantana et. al. (2004) consider this question in the context of institutional trading. They claim that differential market reactions to buy and sell trades depend on market conditions. They argue that in bullish markets the suppliers of liquidity will not push down prices, following a sell order, as it is easy to find a buyer. In contrast, in bearish markets institutions have to offer discounts to find buyers for their sell orders, which results in buys (sells) having a bigger and permanent price impact in bullish (bearish) markets. On the other hand, Friederich et. al. (2002) assert that an additional reason for contrarian trades to be informative, is that in bearish markets there is a high demand for good stocks which depress the price of smaller stocks. Corporate insiders may see this as the time to buy stocks at bargain prices if they have 'inside' information about the stocks. To our 
knowledge, no study considers this impact in the case of insider trading. Therefore, we set up the following hypothesis:

Hypothesis 3: There is no difference in price impact between the bull and bear market condition of buy and sell trades.

Rozeff and Zaman (1998) show that insider transactions are not random across growth and value stocks. Insider buying increases as stocks change from growth to value categories. Insiders buy heavily in value stocks and sell glamour stocks (Lakonishok and Lee, 2001 and Jenter, 2005). Gregory, Tharyan and Tonks (forthcoming) report that directors buy (sell) in value (glamour) stocks earn positive (negative) returns and they persist up to two years after the directors' trades. They also report that abnormal returns are particularly concentrated in smaller value stocks. All of the aforementioned studies examine the value-glamour strategy in the long run. Recognising the fact that value-glamour strategy are more relevant in the long run it would be useful to examine the market reaction to insider trading in the short run in the UK where trades are reported relatively quicker.

Hypothesis 4: Market reaction is higher (lower) for value (glamour) stocks in the short run.

The existing literature clearly demonstrates that insiders trade in small companies, and earn higher abnormal returns. In contrast, when they trade in large companies excess returns are relatively small. For instance, in the US, Lakonishok and Lee (2001) find that insider trades in small companies convey more information compared to large companies, when measured around the reporting period. In the UK, Gregory, Matatko, Tonks and Purkis (1994) find that the abnormal returns are concentrated in smaller firms. After the seminal work by Fama and French (1993), the variable size becomes important in event studies. In the insider trading literature, the importance of size cannot be overlooked (e.g., Gregory, Matatko and Tonks, 1997). Moreover, there is evidence that the buy trades of insiders are mainly concentrated in small firms (Seyhun, 1986; Rozeff and Zaman, 1988). In addition, Loughran 
and Ritter (2000) argue that the behavioural timing depends on undervaluation, and it is easier to take advantage of any undervaluation in small firms, because if the stocks are mispriced, the arbitrage forces will push the prices towards their fundamental values. Hence, correcting the misvaluations for any large firms compared to small firms. These arguments suggest the following hypothesis.

Hypothesis 5: The market evaluation of insider trading is expected to be dependent on the size of the company to reflect the level of asymmetric information and risk.

Jenter (2005) finds little evidence that managers use inside information in their trades. The excess returns after controlling for size and book-to-market effects are indifferent from zero. However, these results do not suggest that managers never use valid inside information when making private and corporate decisions. He argues that his results are consistent with Lakonishok and Lee (2001) who document that insider trading does not predict subsequent returns, once size and book-to-market effects are controlled for. There is some predictability of excess returns in the case of equity purchases in small firms, but no predictability of excess returns is found for the sell trades. On the other hand, recent research using UK data shows that insider buy and sell trades trigger an immediate market reaction of $1.16 \%$ and $-0.26 \%$ respectively (Fidrmuc et al., 2006). We test whether insider trades in the UK convey information after controlling for $\mathrm{M} / \mathrm{B}$ and size effects.

Hypothesis 6: After controlling for size and $M / B$, the excess returns of insider trades are not different from zero.

Insiders' possess superior information about the firm and information asymmetry is the focal point to insider trading (Aboody and Lev, 2000). If there are environments of symmetric information, insider trades would have hardly triggered any market reactions. In a market with higher level of information asymmetry insider trades will have a higher price impact (see, for instance, Kyle, 1985; and Milgrom and Stokey, 1982). Hence, asymmetric 
information should be positively related to the variance of returns. Marin and Oliver (2008) define market crash and jumps in terms of standard deviations and find a relationship with insider trading. We hypothesise here that volatility is positively related to the market reaction to insider trades. Therefore:

Hypothesis 7: Insider purchases (sells) triggers higher (lower) market reaction for high volatility stocks.

\section{Data}

This research uses Directors Deals, a large database of all UK firms' directors' trades spanning from January 1999 to December 2007, to collect data on trades undertaken by insiders of our sample companies. The database includes news items on directors' trades disclosed by all UK firms to the Regulatory News Service (RNS). We exclude a number of observations that are not likely to be driven by private information, such as exercise of options or derivatives, script dividends, bonus shares, rights issues, awards made to directors under incentive plans or reinvestment plans. Also all directors' transactions in investment companies are excluded. After this screening, we obtain 36,943 insiders' trades from the UK market. We check the data for errors and exclude $2,952(8 \%)$ trades as the difference in announcement and transaction date is more than 5 days. The final sample includes 33,991 directors' trades in 2,664 listed companies, split into 26,268 (77\%) purchases and 7,723 (23\%) sell trades. This insider-trading database includes transaction price, amount, and value, post-transaction holding, change in holding, name and position of the insider, and announcement and transaction dates, as UK insiders can delay up to five days the announcement of their trade, but most report their trades on the RNS on the transaction date (Korczak and Lasfer, 2009). 
The sample period covers two interesting sub-periods: the bull period (January 1999 to March 2000 and January 2004 to December 2007) and the bear period (April 2000 to December 2003) in the stock markets, which allows us to test whether insiders time their trades differently under different market conditions. Adjusted daily share prices, data on FTSE All Share Price Index, market capitalization, market- to-book ratio are taken from

\section{DataStream.}

\section{Market Return and Aggregate Insider Trading}

\subsection{Measure of Aggregate Insider Trading}

It is expected that insiders react to market returns if they are contrarians (Jiang and Zaman, 2010). Also, we expect market returns to "predict" aggregate insider transactions (see Rozeff and Zaman, 1998; Chowdhury, Howe and Lin, 1993; and Lakonishok and Lee, 2001). Such a relationship is consistent with the proposition that insiders follow a contrarian investment strategy. This paper tests whether insiders are contrarians by using aggregate insider transactions. If insiders are contrarians, it is expected that market returns will affect aggregate insider trading. In other words, an increase (decrease) in market price will lead insiders to sell (buy). We then relate insider sell (buy) to market conditions as measured by bull (bear) markets. Since, in the bull market prices are up, higher insider sells are expected. In contrast, in bear market prices are down, hence higher insider purchases are expected.

Following Lakonishok and Lee (2001), this paper uses net purchase ratio (NPR) which is the ratio of net purchases to total insider transactions, for measuring the aggregate insider trading activities. Each month starting from January 1999 to December 2007, the total numbers of insider purchases and sells are calculated. Pound Sterling volumes of insider trading are also computed. We then calculate the NPR by dividing the net aggregate number (volume) of insider purchases by the total aggregate number (volume) of insider transactions. 
We use market returns for 6,12 and 24 month horizons as a predictor of insider trades. Return on FTSE All Share price index is used as a proxy for market return. Figure 1 shows that there is a negative relationship between NPR and market returns, which supports the contrarian behaviour.

[Insert Figure 1 here]

The following regression model is estimated to examine the relationship between aggregate insider trading and return on market:

$$
\mathrm{NPR}_{\mathrm{t}}=\alpha+\beta \mathrm{PR}(\mathrm{k})_{\mathrm{t}}
$$

Where, NPR is the aggregate insider trading activity in month $\mathrm{t}, \mathrm{PR}(\mathrm{k})_{\mathrm{t}}$ is the prior k-holding period return on market at time t. A negative relationship is expected between NPR and priorreturn as contrarian strategy implies a buy (sell) after a price decline (rise). Since, NPR is positive (negative) if insiders are net buyer (seller) then we expect prior-return (PR) should be negatively related to NPR.

\subsection{Regression results}

\subsubsection{Impact of pre-event returns on aggregate insider trading}

We use 6-, 12-, 24- month prior return to examine whether the insiders buy (sell) as a reaction to market returns. Table 1, Panel-A and Panel-B, reports regression results based on NPR number of transactions and NPR money volume, respectively. In all the regressions, we find that prior-return over k-period is statistically and economically significant. The negative sign of PR implies that insiders are contrarians and suggest that insiders sell after a price rise, and they buy after a price decline. The results are consistent with Lakonishok and Lee (2001) and Jiang and Zaman (2010).

[Insert Table 1 here] 
Although all the coefficients of prior-return are negative, the coefficient of PR becomes smaller as the holding period become longer. For example, the coefficient is -2.02 when 6 month prior return is used compared to -0.55 when 24 month prior return is used. This provides evidence that insiders rely more on recent price performance. The adjusted $\mathrm{R}^{2}$ also declines from $23.7 \%$ to $8 \%$. Similar results are obtained using the NPR measure based on money volume. The predictive power of money volume based NPR is higher than the number of transaction based NPR. It may imply that when market moves are larger insiders make large trades.

\subsubsection{Aggregate insider trading in bear and bull markets}

After examining the relationship between market return and aggregate insider trading activity, this study follows a similar methodology to test whether insiders' trading is related to market conditions. Net purchase ratio (NPR) is used as aggregate measure of insider trading activity. The following model is estimated:

$$
N P R_{t}=\alpha+\beta \mathrm{BB}+\gamma \mathrm{PR}(\mathrm{k})_{\mathrm{t}}
$$

BB is a dummy equal to one for two periods: January 1999 to March 2000 and January 2004 to December 2007. Bear market is from April 2000 to December 2003. $\mathrm{NPR}_{t}$ is the NPR of aggregate insider trading activity in month $\mathrm{t}, \mathrm{PR}(\mathrm{k})_{\mathrm{t}}$ is the prior $\mathrm{k}$ holding period return on market at time t.

Table 2 shows the mean and median net purchase ratios in the bull and bear markets. We calculate the NPR based on amount of shares traded and Pound Sterling value of trades. The mean NPR (value) for bull and bear market is -0.59 and -0.23 , respectively. It shows that the NPR is more negative when the market is in bullish state compared to bearish state. The medians are very closer to means. NPR (amount) shows that in bull market it is negative 
while in bear market it is positive, suggesting that insiders are net sellers in bull market and net buyers in bear market.

\section{[Insert Table 2 here]}

Figure 2 shows that in bear market most of the NPRs are positive suggesting that insiders are net buyers. In bull market (shaded area) most of the NPRs are negative, meaning insiders are net sellers.

\section{[Insert Figure 2 here]}

Table 3 reports the results on the regressions. In the first regression, we only use the BB dummy as an independent variable to examine the effect of bull (bear) market on NPR. In the other regressions, we use 6-, 12-, 24-month prior returns with the BB. The results are consistent with the notion that insiders buy trades increases in bear market and insider sell trades is higher in the bull market. Both the NPR measures are negatively related to BB dummy, suggesting that insider buy in the bear market with an expectation to sell in the bull market. Table 3 shows that insiders use the bull (bear) markets as a platform to act like contrarians. The evidence holds even after controlling for the contrarian behaviour of the insiders by incorporating prior-returns. After controlling for contrarian strategies, it is shown that insiders further use bull (bear) market to time the market. For example, in Panel A, the second regression shows that after controlling for 6-month prior returns insiders use bull (bear) market to sell (buy) securities.

\subsubsection{Predictability of post trade returns}

The previous section reports that insiders are contrarians. Here, it is tested whether the aggregate insider trading predicts future market returns. If insider trades are informative, a positive relationship between aggregate insider trading measure (NPR) and future market return is expected. The following regression is estimated to examine the relationship between aggregate insider trading and return on market: 


$$
\prod_{t=k}^{\mathrm{t}+\mathrm{T}}\left(1+\mathrm{R}_{\mathrm{M}, \mathrm{k}}\right)-\prod_{\mathrm{t}=\mathrm{k}}^{\mathrm{t}+\mathrm{T}}\left(1+\mathrm{R}_{\mathrm{f}, \mathrm{k}}\right)=\alpha+\beta \mathrm{NPR}_{\mathrm{t}}+\gamma \mathrm{PR} 24_{\mathrm{t}}
$$

Where, $R_{\mathrm{M}, \mathrm{k}}$ is the market return in month $\mathrm{k}, \mathrm{R}_{\mathrm{f}, \mathrm{k}}$ is the monthly treasury bill rate in month k, $\mathrm{NPR}_{t}$ is the NPR of aggregate insider trading activity in month t, PR24 $t$ is the prior two year holding period market return at time $\mathrm{t}^{5}$. We include the prior two year holding period return in the regressions to control for the fact that insiders are contrarians, following Lakonishok and Lee (2001). We also control for the momentum factor documented in previous studies, as stocks that perform the best (worst) over a 3 to 12 month period tend to continue to perform well (poorly) over the subsequent 3 to 12 months (Jagadeesh and Titman, 2002). We control for the fact that the current market return is affected by the previous market returns. By doing this, it would be possible to separate out the insider's information from simple contrarian strategy/momentum effect.

\section{[Insert Table 4 here]}

Table 4 reports the regression results for 3, 6, 9 and 12 month holding period. The coefficient NPR is negative and significant in most of the regressions. For example, Panel A, Table 4 shows that the coefficient of NPR is $-0.05(t=3.28)$ for the 3-month holding period, which shows that insider trading predict stock prices contrary to the expectations. For the alternative holding periods the results are qualitatively similar. For money volume, similar results are obtained for holding periods 3 and 9, while for holding periods 6 and 12 the coefficient is not significant. Overall, the results show that insider trading predicts market return in the opposite directions to expectations. The negative coefficient of NPR is contrary to the findings of earlier studies done in the US market (e.g., Lakonishok and Lee, 2001) suggesting that the aggregate insider trading does not convey enough information to forecast future prices. Since the insider trades in the UK market are reported within 6 days, the information is short-lived. ${ }^{6}$ It might be possible that insider trading in the UK does not covey 
enough information to predict the aggregate market returns. Since insiders are net sellers (as NPR is negative for most of the time period) and individual sell trades do not convey information (as the returns are statistically and economically insignificant) the results of aggregate insider trading is partially consistent with that.

\section{Event Period Returns}

\subsection{Descritive Statistics and Information Content of Insider trades}

Table 5 presents the descriptive statistics and t-tests for differences in means. Panel A presents the mean differences for company fundamentals. We measure size as the market value of equity before 5 days of the trade, M/B as the market value to book value of equity before 5 days of the trades, Stock volatility as standard deviation of stock measured from -240 to -41 days window relative to the trade, and market volatility as standard deviation of market index over the same window. The results show strong differences between buy and sell trades. The average company size for buy and sell trades are different, and, a t-test of differences in means shows that they are statistically different. This is an early indication that the stocks insiders buy and they sell are different, which is consistent with previous literature (e.g. Lakonishok and Lee, 2001). The average $M / B$ is also different for buy and sell trades. Furthermore, the mean difference t-test shows that they are statistically different.

Table 5, Panel B, reports the results on the market reaction to insiders' trades. For the whole sample the cumulative abnormal returns for buy trades over the pre-event periods [-40, -2] is negative and highly significant. In contrast, before the sell trades the abnormal returns are positive and significant. The results clearly indicate the contrarian strategies adopted by insiders and the impact of the trades on the announcement dates as well as the post-trade performance. 
The event day and post-event day returns for buy trades are positive and significant. In contrast, for the sell trades, the event day returns are negative, but not significant ${ }^{7}$. Interestingly, the post-event day abnormal returns are not negative and not significant for sell trades. After the buy trades, share prices recover to a certain extent. However, after the sell trades, share prices do not decline, rather the trend stops and share prices level off. These results support the earlier findings that the buy trades convey information, but the sell trades are not informative (Lakonishok and Lee, 2001). The t-test of differences in mean shows that the buy and sell trades are different.

\section{[Insert Table 5 here]}

Lakonishok and Lee (2001) note that the abnormal returns around the reporting dates are not economically meaningful, though, statistically significant. For example, they report abnormal returns of $0.13 \%$ and $-0.23 \%$ for purchases and sells, respectively around reporting day. However, their findings are contrary to our results where we find abnormal returns of $1.02 \%$ and $-0.13 \%$ for buy and sell trades respectively. In addition, we find that the abnormal returns for the buy trades are statistically and economically significant when measured around the announcement date, which is consistent with Fidrmuc et al. (2006).

\subsection{Market Sentiment and Price Impact of Insider Trades: Univariate Results}

This study examines the price impact asymmetry and hence tests for market timing by splitting the sample period into bull (01/1999 to $03 / 2000$ and $01 / 2004$ to $12 / 2007)$ and bear (04/2000 to $12 / 2003)$ periods. We find that the behaviour of share prices following buy and sell trades does not depend on market conditions (Table 6). The mean difference t-tests show that the behaviour of CAR's over different event windows is not significantly different. The only exception to this is that buy trades over the estimation window $[-40,-2]$ in bull and bear markets show significant differences. Our results are in line with Korczak and Lasfer (2009), who find that the behaviour of share prices following buy and sell trades does not depend on 
market conditions. These findings are in contrast with Chiyachantana et al. (2004) who assert that in a bull market, suppliers of liquidity are suspicious of buy orders, and run up the prices in the face of a strong buying interest.

\section{[Insert Table 6 here]}

Chiyachantana et al. (2004) argue that suppliers of liquidity are not so cautious about the institutional sell orders in a bullish environment and do not run down prices so much when they face selling interests. In bearish markets the situation is exactly the opposite. In a bullish market, buys have a bigger price impact, and in bearish markets sells have a bigger price impact. However, we find evidence, which is almost contrary to this argument. The absolute magnitude of CARs for buy trades in bear periods are higher than the bull period trades [5.53 vs. $-3.14,1.12$ vs. $0.92,2.23$ vs. 2.03 over the event window $(-40,-2),(-1,+1),(+2,+40)$ respectively]. The only evidence which is consistent with Chiyachantana et al. (2004) is the absolute magnitude of the sell trades' CAR in the bear period, which is higher than sell trade $[-0.26$ vs. -0.001 over the event window $(-1,+1)]$. However, for both buy and sell trades, we do not find any significant difference in price response in bull and bear periods.

\subsection{Market-to-book Quintiles: Univariate Analysis}

The previous section examines the price impact asymmetry in bull (bear) markets. This section assesses whether there are any connections between company fundamentals and the timing of insider trades. By following Rozeff and Zaman (1998), Lakonishok and Lee (2001) and Jenter (2005), we hypothesize that insiders' perceptions of fundamental value diverge systematically from market valuations, and the perceived mispricing is an important determinant of the insiders decision making. The tests in this section are also consistent with value strategies, where investors buy low M/B stocks, which have performed poorly in the past and sell stocks with high $\mathrm{M} / \mathrm{B}$ which performed well in the past. 
We form quintiles according to $\mathrm{M} / \mathrm{B}$ ratios to test whether insiders buy undervalued shares, and sell overvalued shares and whether they time their trades. A major difference between the current study and Rozeff and Zaman (1998) and Lakonishok and Lee (2001) is in forming those quintiles. Rozeff and Zaman (1998) rank their companies into deciles each year by annual book-to-price ratios. Similarly, Lakonishok and Lee (2001) divide their sample into three book-to-market (B/M) groups based on the $\mathrm{B} / \mathrm{M}$ ratio at the end of April of each calendar year. The annual measures are not likely to be good proxies for market mispricing and insiders timing in the context of individual insider trading where the trades are announced daily. Lakonishok and Lee (2001) examine whether value (growth) strategy adopted by insiders can earn different returns in the long run. However, in this paper our objective is to examine whether there is any significant difference in the market reaction to insider trading in the short run in value and growth stocks. That is why, we compute the market-to-book ratios 5 days announcement dates to form M/B quintiles. M/B ratios for all trades are obtained for 5 days prior to the trade. The companies are sorted in quintiles each year by M/B ratios. Similar procedures are applied to form quintiles based on size. This study tests the hypothesis that insiders buy (sell) shares in their own company if they perceive that their company is under- (over-) valued. We analyse the short-term abnormal returns in the pre-trade $(-40,-2)$ and post-event $(+2,+40)$ periods. We then split the sample into quintiles based on each firm's market-to-book ratio. The market-to-book is estimated 5 days prior to the trade, for capturing the insiders' decisions. If their decision to trade is based on market-tobook, it should be as close as possible to the announcement date of the trade and not the beginning of the year. Low (high) M/B companies are expected to generate higher (lower) abnormal returns in the post-trade periods, if insider trading signals under- (over-) valuation, and the market revalues these companies after the trade. The pre-event return will be higher 
as we move from low $\mathrm{M} / \mathrm{B}$ to high $\mathrm{M} / \mathrm{B}$ quintiles. On the other hand, the event and post event returns will be smaller as we move from low to high $\mathrm{M} / \mathrm{B}$ quintiles.

The analysis of M/B quintiles show evidence of signalling over- (under-) valuation (Table 7, Panel A; and Figure 3). Low M/B companies (value stocks) are companies that are perceived to be undervalued. We expect insiders in these companies to signal undervaluation when they purchase shares, resulting in positive post-event abnormal returns. As expected, for buy trades, as we move from low M/B to high M/B stocks, the post event abnormal returns are getting smaller. For example, the CAR for quintile 1 is $3.46(t=5.72)$ and for quintile 5 is $0.79(t=1.08)$ in the post event window. The mean difference $t$-test indicates that quintile 1 is statistically different from quintile 5 . Also, the chi-square test for differences among the means reject equality of means. The results on pre-event returns also support our expectations. As we move from low $\mathrm{M} / \mathrm{B}$ to high $\mathrm{M} / \mathrm{B}$ stocks, the pre event abnormal returns are larger. The means of 'value' (low M/B) and 'glamour' (high M/B) stocks are different. Moreover, the chi-square test shows differences among the means. When insiders buy in low $\mathrm{M} / \mathrm{B}$ companies, the immediate price reaction of trades and price recovery is much higher, compared to high $\mathrm{M} / \mathrm{B}$ companies. This is consistent with value strategies.

[Insert Figure 3 here]

In contrast, high M/B stocks are glamour stocks, which are likely to be over-valued. The post-sell trades' abnormal returns in these companies should be negative. Table 7, Panel B and Figure 4 show that for sell trades do not show very strong evidence of signalling overvaluation. Only, the pre-event window CARs show some evidence of insiders' systematic trading based on their perceptions about the company. For example, the CARs are getting higher as we move from value stocks to glamour stocks in the pre-event period, which is consistent with theory. There are also differences in mean between value and glamour stocks. However, the chi-square test does not indicate that there are significant differences among the 
quintiles. The event-day and post-event day returns are not fully consistent with predictions. None of the CARs across the M/B quintiles are statistically significant. The mean difference t-test is not significant and the chi-square test shows there are no significant differences among the means. Overall, insiders sell after a significant rise in prices and the trend stops following their sell trades. Hence, there is weak evidence of timing. Our results suggest that insiders are able to time their trades, but they are not fully capable of changing the market's perception regarding their firm's true value. In sum, the results provide partial support for the proposition that insiders follow growth strategies when they sell their shares.

[Insert Figure 4 here]

\subsection{Size Quintiles: Univariate Results}

Table 8, Panel A and Figure 5 show the univariate results on size quintiles. The results show that there is evidence of market timing by the insiders for small stocks. If managers have timing abilities in small companies, we expect pre-event cumulative abnormal returns to be higher as we move from small to large companies. Also, event and post-event abnormal returns will be lower as we move from small to large companies. In the case of buy trades, even though the signs are as predicted the pre-event returns do not increase as expected when moving through the quintiles. For instance, for smallest size quintile CAR is $-2.25(t=-2.69)$ compared to $-2.93(\mathrm{t}=-4.87)$ for large size quintile stocks. The mean difference $\mathrm{t}$-test between small and large companies is statistically insignificant, but the chi-square test for the differences in means for different quintiles is highly significant.

\section{[Insert Table 8 here]}

In terms of event and post-event CARs the results are in line with our expectations. For example, the event day CARs are gradually declining as we move from small to large companies $(3.02,1.22,0.76,0.15$ and -0.12 respectively with the latter two not being statistically significant). The post-event CARs also show similar patterns $(2.95,3.47,2.36$, 
0.94, 0.48 respectively, with all being significant except the last one). Furthermore, the mean difference t-test between small and large companies shows significance at $1 \%$ level for event day and post-event abnormal returns. The evidence is substantiated by the chi-square test which shows that there is significant difference across the means over the different quintiles for both event-day and post-event returns. Overall, the results support the proposition that insiders buy shares after a significant price decline; that after purchases share price recovers; and that this behaviour is more pronounced for small firms.

The results for the sell trades do not provide strong evidence of market timing in the case of small companies (Table 8, Panel B and Figure 6). The pre-event window CARs show mixed evidence of managers' systematic trading based on their perceptions about the company. For example, the CARs are getting higher as we move from quintile 1 to quintile 3 and then decline again. Additionally, there are no significant differences in means between small and large stocks and the differences across the quintiles are not statistically significant. The event-day and post-event day returns are not fully consistent with our predictions. None of the CARs across the size quintiles are statistically significant, except the post-event return for quintile 1 . The mean difference t-test is not significant for event-day returns and the chisquare test shows that there are no significant differences among the means. Overall, insiders sell after a significant rise in prices and the trend stops after they sell. This shows weak evidence of timing. Therefore, the results indicate that insiders are able to time their buy trades but not their sell trades in the case of small companies. This is consistent with Lakonishok and Lee (2001) in the US and Gregory, Matatko, Tonks and Purkis (1994) in the UK, who find that insiders timing ability is more pronounced in small firms.

\subsection{M/B and Size Sorting of Abnormal Returns}

This section provides two-way sorting based on $\mathrm{M} / \mathrm{B}$ and size. The purpose of two-way sorting is to examine the effect of $\mathrm{M} / \mathrm{B}$ and size simultaneously. Jenter (2005) shows that 
insiders' trades in the US hardly convey any information after controlling for $\mathrm{M} / \mathrm{B}$ and size. We examine in this section whether the same applies in the UK. In the case of buy trades, most of the results in earlier analysis were driven by small companies and low $\mathrm{M} / \mathrm{B}$ companies (Table 9). For example, the event period returns show that all the returns across $\mathrm{M} / \mathrm{B}$ quintiles are significant only for small company quintile. None of the event period returns are significant for the large company quintile. In addition, the post-event returns are significant in small company quintile and all the post-event returns are insignificant in large company quintile. This implies after controlling for market to book and size insider purchases do not convey any information.

\section{[Insert Table 9 here]}

For example, the event-day return for largest company quintile and largest $\mathrm{M} / \mathrm{B}$ quintile is even negative $(-0.58, \mathrm{t}=-0.98)$. The post-event return for the largest company and high $\mathrm{M} / \mathrm{B}$ quintile is also negative $(-0.31, \mathrm{t}=-0.23)$. These results are consistent with earlier findings in the US that most of the insider returns are not indistinguishable from zero, once the size and M/B effects are controlled for. However, Lakonishok and Lee (2001) find that the abnormal returns around the reporting dates do not depend on size or $\mathrm{M} / \mathrm{B}$. We find that the reporting period abnormal returns are directly related to $\mathrm{M} / \mathrm{B}$ and size. Our results are consistent with the view that smaller companies are associated with more information asymmetry and hence the market reaction is higher. Smaller companies are also more risky, which may yield higher returns when insiders trade.

\section{[Insert Table 10 here]}

\subsection{Stock and Market Volatility sorting}

In this section, we sort the CARs from low to high stock volatility ${ }^{8}$. The results show that for buy trades, low volatility stocks display lower price drops in the pre-event window and the market reaction is smaller immediately and post-event period compared to the high volatility 
stocks. The mean difference between low and high volatility is highly significant. In addition, we find that the means are different across all the quintiles for the pre-event and event window. However, for sell trades, the CAR is lower for low volatility stocks during the preevent window compared to high volatility stocks. Furthermore, the means between high and low volatility stocks are significantly different and the chi-square test, shows that the means across quintiles are not homogenous. The results imply that insiders have more knowledge in high volatile stocks.

When we sort the stocks based on market volatility the results are similar. For buy trades, the higher the market volatility prior to the trades, the higher the market reaction. This holds for both the event and the post-event window. The post-event market reaction for low volatility $(0.97 \%)$ is significantly lower compared for high volatility $(3.46 \%)$. Regarding the sell trades, they are preceded by high market volatility and the market reaction in the postevent period is positive and significant $(1.89 \%$ with $\mathrm{t}=2.93)$. The mean difference between low and high is highly significant, and chi square rejects the null of homogeneity. In sum, we find that high (low) stocks, and market volatility prior to the insiders' trades is related to high (low) market reaction.

[Insert Table 11 here]

\subsection{Cross Sectional Variation in Abnormal Returns}

This section runs cross-sectional regressions to control for a number of factors simultaneously. The overall results of univariate analysis show that insiders buy (sell) undervalued (overvalued) stocks as measured by $\mathrm{M} / \mathrm{B}$ and find evidence of market timing in the purchase of small company stocks. In particular, as we move from low to high quintiles for $\mathrm{M} / \mathrm{B}$, size, stock volatility and market volatility for the pre-event, event and post-event abnormal return varies. Clearly, these provide evidence that the abnormal returns vary with $\mathrm{M} / \mathrm{B}$, size, stock volatility and market volatility. 
Therefore, we estimate the following model seperately for the buy and sell trades:

$$
\begin{aligned}
C A R_{j}=\alpha+\beta_{1} \operatorname{Ln}\left(\text { Size }_{j}\right. & +\beta_{2} M / B_{j}+\beta_{3} \text { Stock }_{\text {Vol }}+\beta_{4} \text { MktVol }_{j}+\kappa B B D u m \\
& +\gamma \text { Year }+ \text { OIndustry }
\end{aligned}
$$

where:

Ln (size) is $\log$ of firm size measured as market value of equity 5 days before the trade, $M / B$ is market-to-book ratio, where market value of equity is taken 5 days before the trade and the book value is the book value of equity at balance sheet date, Stock Vol is standard deviation of stock returns over -240 to-41 days, $M k t$ Vol= is standard deviation of market returns over 240 to-41 days, $B B$ Dum is a dummy equal to 1 for Bull Market.

In order to isolate the pure cross-sectional component of the $\mathrm{M} / \mathrm{B}$ and size effect on insider trading, a set of regressions are estimated using the entire sample period from 1999 to 2007. The results are reported in Table 12. The M/B effects are negative and significant in the case of buy trades, suggesting that managers buy undervalued stocks. These findings are consistent with the $\mathrm{M} / \mathrm{B}$ quintile analysis. Therefore, the insider trading decisions are influenced by the relative market valuations. We also examine the impact of size on insiders' market timing ability. The coefficient is negative and significant for the buy trades, which is consistent with the evidence that insiders try to time the market in case of small companies. For buy trades, both the stock and market volatility are positive and significant in most cases, suggesting that risky stocks earn higher returns, and high market volatility is related to higher returns. This is consistent with Huddart and Ke (2006), who assert that for companies where information asymmetry is higher, the abnormal returns are higher. In sum, the results suggest that insiders time their buy trades.

[Insert Table 12 here]

For sell trades, M/B has a positive but not significant relationship (Table 12). The sign is consistent with our predictions suggesting that insiders sell overvalued stocks. 
Furthermore, size has a negative relationship and market volatility has a positive relationship but only for the post-event market reaction CAR $(+2,+40)$. Overall, the results suggest that $\mathrm{M} / \mathrm{B}$, size and market volatility significantly affect the market's reaction to insider trading.

Finally, the documented pattern of insider purchases and sells across $M / B$, size, stock volatility and market volatility quintiles could also be due to some omitted variable measuring and unobserved heterogeneity across firms in different quintiles. One crude measure of heterogeneity across firms is the industry in which they operate. It is well established that the market-to-book ratios in the same industry tend to move together and that several industries are characterized by extreme valuations. Some particular businesses are considerably more investment intensive and the company size of that industry can be larger than other industries. Therefore, in order to determine whether the market-to-book and size effect on insider trading is simply an industry effect, we incorporate industry dummies in the regressions. Finally, for assessing whether the results are not time dependent, we also include year dummies in our regressions. In none of the cases, the industry dummies or year dummies are significant, suggesting that our results are not driven by industry or time effects.

\section{Conclusion}

This study employs a unique data set to test whether insiders time their trades or not. This is one of the first studies to examine aggregate in insider trading in the context of UK. We find that on an aggregate basis, insiders are contrarians but aggregate insider trading does not predict monthly returns. This is consistent with the view that the information content of insider trading is limited to the period surrounding the announcement dates. We then examine whether insider trading is related to the market sentiment as measured by a bull (bear) market. The aggregate insider trading activity shows a relationship between insiders' market timing and market sentiment as measured by bull (bear) periods. This provides evidence that 
insiders use market sentiment as a platform to act like contrarians. However, we do not find a significant difference in the price response during bull and bear periods.

Further, this study examines whether there are any relationships between company fundamentals and the timing of insider trades, as addressed in Rozeff and Zaman (1998), Lakonishok and Lee (2001), Jenter (2005) and Gregory et al. (forthcoming). Insiders tend to buy stocks with poor past performance, and those that are cheap according to proxies such as the market-to-book ratio. Consistent with the existing literature, the insiders' ability to time their trades is not homogeneous across all market capitalization groups. Insiders have a relative advantage in timing, in the case of small stocks compared to large stocks. Additionally, the results show that insider purchases convey information, while sells are not associated with low returns. This is consistent with Kallunki, Nilstrom and Hellstrom (2009) who report that portfolio rebalancing, tax consideration and behavioural biases are the most important reasons for insider trading. We show that the information asymmetry has an important impact on the market reactions to insider trades as in Kyle (1985).

The results call into question as to whether insiders are able to earn excess returns with their trades when controlling for size and M/B effects. Recent insider trading literature confirms the finding that most excess returns to insider trades can be explained by the size and $\mathrm{M} / \mathrm{B}$ effects, and suggests that the economically significant excess returns in older studies is due to the lack of control for these observable firm characteristics (Jenter, 2005). The most comprehensive study of insider trading by Lakonishok and Lee (2001) shows that most of the return predictability through insider trades vanishes once size and $\mathrm{M} / \mathrm{B}$ are controlled for. However, we find that there is still some predictability of excess returns left when using equity purchases in small firms, but we find no predictability of excess returns on the sell side. Finally, we show that insiders show timing ability in highly volatile stocks, and following high volatility in the market. 


\section{References}

Aboody, D., Lev, B., 2000. Information asymmetry, R\&D, and insider gains. Journal of Finance 55, 2747- 2766.

Brennan, Michael J and H. Henry Cao, 1996, Information, Trade and Derivative Securities, The Review of Financial Studies 9(1), 163-208. 
Chiyachantana, Chiraphol N., Pankaj K. Jain, Christine X. Jiang, and Robert A. Wood, 2004, International evidence on institutional trading behavior and price impact, Journal of Finance 59, 869-898.

Chowdhury, M., J. S. Howe, and Ji-Chai Lin, 1993, The relation between aggregate Insider Transactions and Stock Market Returns, The Journal of Financial and Quantitative Analysis 28, 431-437.

DeLong B., A. Shleifer, L. Summers, and R. Waldmann, 1990, Positive feedback investment strategies and destabilizing rational speculation, Journal of Finance 45, 374- 397.

Fahlenbrach, Rudiger and Rene' M. Stulz, 2011, Bank CEO incentives and the credit crisis, Journal of Financial Economics 99, 11-26.

Fama, Eugene and K.R. French, 1993, Common Risk Factors in the returns on stocks and bonds, Journal of Financial Economics 33, 3-56.

Fidrmuc, Jana, Marc Goergen, and Luc Renneboog, 2006, Directors' share trading, news release and ownership concentration, Journal of Finance 61, 2931-2973.

Friederich, Sylvain, Alan Gregory, John Matatko, and Ian Tonks, 2002, Short-run returns around the trades of corporate directors on the London Stock Exchange, European Financial Management 8, 7-30.

Gregory, Alan, John Matatko, and Ian Tonks, 1997, Detecting information from directors' trades: signal definition and variable size effects, Journal of Business Finance \& Accounting 24, 309-342.

Gregory, Alan, John Matatko, Ian Tonks, and Richard Purkis, 1994, U.K. directors trading the impact of dealings in smaller firms, Economic Journal 104, 37-53.

Gregory, Alan, Rajesh Tharyan, and Ian Tonks, 2011, More than just contrarians: Insider Trading in Glamour and Value Firms, European Financial Management, Forthcoming. 
Hillier, David, and Andrew Marshall, 2002, Are trading bans effective? Exchange regulation and corporate insider transactions around earnings announcements, Journal of Corporate Finance 8, 393-410.

Huddart, Steven and Bin Ke, 2006, Information asymmetry and cross sectional variation in insider trading, working paper, Pennsylvania State University

Jenter, Dirk, 2005, Market timing and managerial portfolio decisions, Journal of Finance 60, 1903-1949.

Jiang, Xiaoquan and Mir A. Zaman, 2010, Aggregate Insider trading: Contrarian Beliefs or Superior Information, Journal of Banking and Finance 34, 1225-1236.

Kallunki, Juha-Pekka, Henrik Nilsson, Jorgen Hellstrom, 2009, Why do insiders trade? Evidence based on unique data on Swedish insiders, Journal of Accounting and Economics 48, 37-53.

Knewtson, H.S., Richard W. Sias and David A Widbee, 2010, Style Timing with Insiders, Financial Analysts Journal 66(4), 1-21.

Korczak, A. and M. Lasfer, 2009, Foreign Shareholder Activism and Insider Trading Before Material News Announcements, Cass Business School Working Paper.

Korczak, Adriana, Piotr Korczak and Meziane Lasfer, 2010, To trade or not to trade, the strategic trading of insiders around news announcements, Journal of Business Finance and Accounting, 37(3) \& (4), 369-407.

Kothari, S.P., and Jerold B. Warner, 2007, Econometrics of event studies, in Handbook of corporate Finance, Empirical Corporate Finance, Vol 1, 3-36.

Kyle, A., 1985, Continuous auctions and insider trading, Econometrica 53, 1315-1335.

Lakonishok, J. and I. Lee, 2001, Are insider trades informative?, The Review of Financial Studies 14, 79-111. 
Loughran, Tim and Jay Ritter, 2000, Uniformly Least Powerful Tests of Market Efficiency, Journal of Financial Economics 55, 361-390.

Marin, Jose M., and Jacques P. Oliver, 2008, The dog that did not bark: Insider trading and crashes, Journal of Finance 63, 2429-2476.

Milgroam, P. and N. Stokey, 1982, Information, trade and common knowledge, Journal of Economic Theory 26, 17-27.

Pope, Peter, Richard Morris, and David Peel, 1990, Directors'share trading: Some evidence on market efficiency and directors's share delings in Great Britain, Journal of Business Finance \& Accounting 17, 359-380.

Rozeff, M. S. and M. A. Zaman, 1998, Overreation and Insider Trading: Evidence from Growth and Value Portfolios, Journal of Finance 53(2): 701-716.

Seyhun, H. N., 1988, The Information Content of Aggregate Insider Trading, Journal of Business 61,1-24.

Seyhun, H. N., 1992, Why Does Aggregate Insider Trading Predict Future Stock Returns, The Quarterly Journal of Economics 107, 1303-1331.

Seyhun, Nejat H., 1986, Insiders' profits, costs of trading, and market efficiency, Journal of Financial Economics 16, 189-212.

Shiller, Robert J., 1984., Stock prices and social dynamics, Brookings Papers on Economic Activity, 457-498.

Table 1. Aggregate Insider Trading and Market Return

\begin{tabular}{llll}
\hline Prior Return(months) & Constant & PR & $\overline{\boldsymbol{R}^{\mathbf{2}}}$ \\
\hline \multicolumn{2}{l}{ Panel A: Number of transactions } & & 23.7 \\
\hline 6 & $\mathbf{- 0 . 0 4}$ & $\mathbf{- 2 . 0 2}$ & \\
& $(-1.03)$ & $(-4.44)$ & 18.2 \\
24 & $-\mathbf{0 . 0 4}$ & $-1.32^{* * * *}$ & \\
& $(-0.73)$ & $(-3.36)$ & $\mathbf{8 . 0}$
\end{tabular}

Panel B: Money Volume 


\begin{tabular}{llll}
\hline 6 & $-0.39^{* * * *}$ & $-2.08^{* * * *}$ & 29.6 \\
& $(-10.14)$ & $(-4.71)$ & \\
12 & $-0.39^{* * * *}$ & $-1.26^{* * * *}$ & 19.5 \\
& $(-7.26)$ & $(-3.48)$ & 18.8 \\
& $-0.37^{* * * *}$ & $-0.76^{* * * *}$ & \\
\hline & $(-5.72)$ & $(-3.03)$ & \\
\hline
\end{tabular}

This table reports the regression results from the following model.

$\mathrm{NPR}_{\mathrm{i}, \mathrm{t}}=\alpha+\beta \mathrm{PR}(\mathrm{k})_{\mathrm{i}, \mathrm{t}}+\varepsilon_{\mathrm{i}, \mathrm{t}}$

Where, NPR of aggregate insider trading activity in month $t, P R(k)_{i, t}$ is the prior k-period holding period return on market at time t. We predict market returns for 3, 6, 9 and 12 month horizons. Each month starting from January 1999 to December 2007, we calculate the total numbers of (and the total Pound sterling volume) of insider purchases and sells. We then calculate the NPR by dividing the net aggregate number (volume) of insider purchases by the total aggregate number (volume) of insider transactions. The Newey-West autocorrelation and heteroskedasticity adjusted $\mathrm{t}$-statistics are in the parenthesis. ${ }^{* * * * * * *}$ represent significant at 1,5 and 10 percent level respectively.

Table 2. Mean Differences in NPR between Bull and Bear Markets

\begin{tabular}{|c|c|c|c|c|c|}
\hline & \multicolumn{2}{|c|}{ Mean } & \multicolumn{2}{|c|}{ Median } & \multirow[b]{2}{*}{ P-value of mean diff. (bull-bear) } \\
\hline & Bull & Bear & Bull & Bear & \\
\hline NPR (amount) & -0.25 & 0.12 & -0.28 & 0.11 & 0.00 \\
\hline NPR (value) & -0.59 & -0.23 & -0.62 & -0.28 & 0.00 \\
\hline
\end{tabular}

This table represents mean (median) of net purchase ratio for each month from January 1999 to December 2007. The bull market and contains two periods (January 1999 to March 2000 and January 2004 to December 2007). For each month, we calculate the total numbers of (and the total Pound Sterling volume) insider purchases and sells. We then calculate the NPR by dividing the net aggregate number of insider purchases by the total aggregate number of insider transactions.

Table 3. Aggregate Insider Trading and Bull/Bear market

\begin{tabular}{|c|c|c|c|c|}
\hline $\begin{array}{l}\text { Prior return } \\
\text { (Months) }\end{array}$ & Constant & BB Dummy & PR & $\overline{R^{2}}$ \\
\hline \multicolumn{5}{|c|}{ Panel A: Number of transactions } \\
\hline & 0.12 & $-0.37^{* * * *}$ & -- & 16.1 \\
\hline & $(\mathbf{1 . 1 8})$ & $(-3.27)$ & & \\
\hline \multirow[t]{2}{*}{6} & 0.04 & $-0.17^{*}$ & $-1.57^{* * * *}$ & 25.3 \\
\hline & $(\mathbf{0 . 6 3})$ & $(-1.89)$ & $(-3.12)$ & \\
\hline \multirow[t]{2}{*}{12} & 0.03 & -0.16 & $-0.89^{*}$ & 18.7 \\
\hline & $(0.43)$ & $(-1.17)$ & $(-1.80)$ & \\
\hline
\end{tabular}




\begin{tabular}{|c|c|c|c|c|}
\hline 24 & $\begin{array}{c}\text { 0.12 } \\
(1.18)\end{array}$ & $\begin{array}{l}-0.37^{* * * *} \\
(-2.45)\end{array}$ & $\begin{array}{c}\mathbf{0 . 0 0} \\
(\mathbf{0 . 0 0 )}\end{array}$ & 15.3 \\
\hline \multicolumn{5}{|c|}{ Panel B: Money Volume } \\
\hline & $\begin{array}{l}-0.22^{* *} \\
(-2.09)\end{array}$ & $\begin{array}{c}-0.37^{* * * * 4} \\
(-3.24)\end{array}$ & -- & 18.1 \\
\hline 6 & $\begin{array}{l}-0.32^{* * *} \\
(-4.54)\end{array}$ & $\begin{array}{l}-0.15^{*} \\
(-1.65)\end{array}$ & $\begin{array}{l}-1.70^{* * * *} \\
(-3.20)\end{array}$ & 31.0 \\
\hline 12 & $\begin{array}{c}-0.30 \\
(-3.84)\end{array}$ & $\begin{array}{c}-0.18 \\
(-1.51)\end{array}$ & $\begin{array}{l}-0.79^{*} \\
(-1.99)\end{array}$ & 20.6 \\
\hline 24 & $\begin{array}{c}-0.28 \\
(-3.85)\end{array}$ & $\begin{array}{l}-0.20^{*} \\
(-1.90)\end{array}$ & $\begin{array}{l}-0.46^{* *} \\
(-2.04)\end{array}$ & 20.9 \\
\hline
\end{tabular}

This table reports the regression results from the following:

$$
\mathrm{NPR}_{\mathrm{i}, \mathrm{t}}=\alpha+\beta \text { BB Dummy }+\gamma \mathrm{PR}(\mathrm{k})_{\mathrm{i}, \mathrm{t}}
$$

Bull Market, $B B$, includes two periods: January 1999 to March 2000 and January 2004 to December 2007. Bear market is from April 2000 to December 2003. $\mathrm{NPR}_{\mathrm{t}}^{\mathrm{i}}$ is the NPR of aggregate insider trading activity in month $\mathrm{t}$, $\mathrm{PR}(\mathrm{K})_{\mathrm{i}, \mathrm{t}}$ is the prior two-year holding period return on market at time t. Each month starting from January 1999 to December 2007, we calculate the total numbers of (and the total Pound sterling volume) of insider purchases and sells. We then calculate the NPR by dividing the net aggregate number (volume) of insider purchases by the total aggregate number (volume) of insider transactions. We use 6, 12 and 24 -month prior returns. The NeweyWest autocorrelation and heteroskedasticity adjusted t-statistics are in the parenthesis. ${ }^{* * * * * * *}$ represent significant at 1,5 and 10 percent level respectively.

Table 4. Predictive Ability of Post-trade Returns

\begin{tabular}{lllll}
\hline Holding Period(months) & Constant & NPR & PR24 & $\overline{R^{2}}$ \\
\hline Panel A & Number of transactions & & & \\
\hline 3 & $-0.01(-1.11)$ & $-0.05(-3.28)^{* * * *}$ & $0.03(0.79)$ & 12.3 \\
6 & $-0.02(-1.22)$ & $-0.07(-2.90)^{* * * * *}$ & $0.04(0.59)$ & 13.9 \\
9 & $-0.03(-1.31)$ & $-0.11(-3.48)^{* * * *}$ & $0.02(0.22)$ & 15.8 \\
12 & $-0.05(-1.40)$ & $-0.14(-3.33)^{* * * *}$ & $-0.01(-0.12)$ & 14.4 \\
& & & & \\
\hline Panel B & Money Volume & & & \\
\hline 3 & $-0.02(-2.49)$ & $-0.04(-1.86)^{* *}$ & $0.03(0.64)$ & 8.0
\end{tabular}




\begin{tabular}{lllll}
6 & $-0.04(-2.06)^{* *}$ & $-0.05(-1.57)$ & $0.05(0.56)$ & 7.6 \\
9 & $-0.06(-1.87)^{*}$ & $-0.07(-1.69)^{*}$ & $0.04(0.30)$ & 5.9 \\
12 & $-0.07(-1.56)$ & $-0.07(-1.25)$ & $0.02(0.14)$ & 2.0 \\
\hline
\end{tabular}

This table reports the regression results from the following model.

$\prod_{t=k}^{\mathrm{t}+\mathrm{T}}\left(1+\mathrm{R}_{\mathrm{M}, \mathrm{k}}\right)-\prod_{\mathrm{t}=\mathrm{k}}^{\mathrm{t}+\mathrm{T}}\left(1+\mathrm{R}_{\mathrm{f}, \mathrm{k}}\right)=\alpha+\beta \mathrm{NPR}_{\mathrm{t}}+\gamma \mathrm{PR} 24_{\mathrm{t}}$

Where, $R_{\mathrm{M}, \mathrm{k}}$ is the return on market in month $\mathrm{k}, \mathrm{R}_{\mathrm{f}, \mathrm{k}}$ is the monthly treasury bill rate in month $\mathrm{k}$, $\mathrm{NPR}_{t}$ is the NPR of aggregate insider trading activity in month $t, P R 24_{t}$ is the prior two year holding period return on market at time t. Each month starting from January 1999 to December 2007, We calculate the total numbers of (and the total Pound sterling volume) of insider purchases and sells. We then calculate the NPR by dividing the net aggregate number of insider purchases by the total aggregate number of insider transactions. We predict market returns for 3, 6, 9 and 12 month horizons. The Newey-West autocorrelation and heteroskedasticity adjusted t-statistics are in the parenthesis. ${ }^{* * *, * * * *}$ represent significant at 1,5 and 10 percent level respectively. 
Table 5. Descriptive Statistics and Market Reaction of Insider Trades

\begin{tabular}{|c|c|c|c|c|c|}
\hline \multirow{2}{*}{ Panel A: } & \multicolumn{2}{|c|}{ Buy trades } & \multicolumn{2}{|c|}{ Sell trades } & \multirow{2}{*}{ ( $\left.\mathbf{p}_{\text {Buy-sell }}\right)$} \\
\hline & Mean & Median & Mean & Median & \\
\hline Size (Market Cap) & 5073.86 & 403.1 & 6817.81 & 403.34 & 0.02 \\
\hline M/B & 2.28 & 1.46 & 3.94 & 2.34 & 0.00 \\
\hline Stock Volatility & 0.023 & 0.021 & 0.022 & 0.019 & \\
\hline Market Volatility & 0.012 & 0.011 & 0.012 & 0.011 & \\
\hline Number of Observations & 26,268 & & 7,723 & & \\
\hline \multicolumn{6}{|c|}{ Panel B: Market Reaction of Insider trades } \\
\hline & \multicolumn{2}{|c|}{ Buy trades } & \multicolumn{2}{|c|}{ Sell trades } & $\left(\mathbf{p}_{\text {Buv-Sell }}\right)$ \\
\hline & Mean & Median & Mean & Median & \\
\hline CAR(-40,-2) & $\begin{array}{c}-4.32 * * * \\
(-15.37)\end{array}$ & -2.16 & $\begin{array}{l}5.60 * * * \\
(10.05)\end{array}$ & 4.90 & 0.00 \\
\hline $\operatorname{CAR}(-1,+1)$ & $\begin{array}{c}1.02 * * * \\
(13.11)\end{array}$ & 0.42 & $\begin{array}{c}-0.13 \\
(-0.83)\end{array}$ & -0.17 & 0.00 \\
\hline $\operatorname{CAR}(+2,+40)$ & $\begin{array}{c}2.13 * * * \\
(7.59)\end{array}$ & 2.04 & $\begin{array}{c}0.24 \\
(0.44)\end{array}$ & 0.64 & 0.00 \\
\hline
\end{tabular}

This table represents descriptive statistics of the companies in our sample and event study results. Panel A represents company fundamentals. Size is the market value of equity before 5 days of the trades, M/B is the market value to book value of equity before 5 days of the trades, Stock volatility is standard deviation of stock measured from -240 to -41 days window, and market volatility is standard deviation from market from the same window. Panel B presents cumulative average abnormal returns around directors' share trading events computed using event study methodology. The market model coefficients $\alpha$ and $\beta$ are estimated over days -240 to -41 relative to the event, with FTSE All Share Index as the proxy for market portfolio. All results are reported relative to directors' share trading announcement day, i.e., the date of the public announcement of directors' share trading. T-statistics are reported in parenthesis. ${ }^{* * * *},{ }^{* *},{ }^{*}$ denote significant at the $0.01,0.05$ and 0.1 level, respectively. 
Table 6. Cumulative Abnormal Returns in Different Market Condition

\begin{tabular}{|c|c|c|c|c|}
\hline Event window & Full Sample & Bear Period & Bull Period & $\mathbf{P}_{\text {Bear-Bull }}$ \\
\hline & \multicolumn{4}{|c|}{ Panel A: Buy } \\
\hline No. of observations & 26,268 & 10,274 & 15,994 & \\
\hline$-40,-2$ & $\begin{array}{l}-4.32^{* \% * \%} \\
(-15.37)\end{array}$ & $\begin{array}{l}-5.53^{3 * \pi \%} \\
(-13.87)\end{array}$ & $\begin{array}{l}-3.14^{* 3 * 6} \\
(-7.39)\end{array}$ & 0.00 \\
\hline$-1,+1$ & $\begin{array}{l}1.02^{* * *} \\
(13.11)\end{array}$ & $\begin{array}{l}1.12^{* * *} \\
(10.14)\end{array}$ & $\begin{array}{l}0.92^{* * * *} \\
(\mathbf{7 . 8 3})\end{array}$ & 0.41 \\
\hline \multirow[t]{2}{*}{$+2,+40$} & $\begin{array}{c}2.13^{* * *} \\
(7.59)\end{array}$ & $\begin{array}{l}2.23^{* * *} \\
(5.60)\end{array}$ & $\begin{array}{l}2.03 \\
(4.77) \\
\end{array}$ & 0.71 \\
\hline & \multicolumn{4}{|c|}{ Panel B: Sell } \\
\hline No. of observations & 7,723 & 2,312 & 5,411 & \\
\hline$-40,-2$ & $\begin{array}{l}5.60^{* * * *} \\
(10.05)\end{array}$ & $\begin{array}{l}5^{5.06} \\
(7.12)\end{array}$ & $\begin{array}{l}\text { 6.11 }^{* * * *} \\
(8.17)\end{array}$ & 0.27 \\
\hline$-1,+1$ & $\begin{array}{c}-0.13 \\
(-0.83)\end{array}$ & $\begin{array}{c}-0.26 \\
(-1.30)\end{array}$ & $\begin{array}{l}-0.001 \\
(-0.01)\end{array}$ & 0.39 \\
\hline$+2,+40$ & $\begin{array}{c}0.24 \\
(0.44) \\
\end{array}$ & $\begin{array}{c}0.76 \\
(1.08) \\
\end{array}$ & $\begin{array}{c}-0.26 \\
(-0.35) \\
\end{array}$ & 0.20 \\
\hline
\end{tabular}

The table presents cumulative average abnormal returns around directors' share trading events computed using event study methodology. The market model coefficients $\alpha$ and $\beta$ are estimated over days -240 to -41 relative to the event, with FTSE All Share Index as the proxy for market portfolio. The full sample includes 33,991 directors' trades in 2,664 listed companies, split into 26,268 purchases and 7,723 sell trades. All results are reported relative to directors' share trading announcement day, i.e., the date of the public announcement of directors' share trading. The bull period covers from January 1999 to March 2000 and January 2004 to December 2007 and the bear period covers April 2000 to December 2003. The last column represents the p-values from mean difference t-test. T-statistics are reported in parenthesis. ${ }^{* * *},{ }^{* *},{ }^{*}$ denote significant at the $0.01,0.05$ and 0.1 level, respectively. 
Table 7. Distribution of Cumulative Abnormal Returns by Market-to-Book

\begin{tabular}{|c|c|c|c|c|c|c|c|}
\hline \multicolumn{8}{|c|}{ Market to Book Quintiles } \\
\hline & Low & 2 & 3 & 4 & High & $\mathbf{P}_{\text {High-Low }}$ & $\chi^{2}(4)$ \\
\hline & \multicolumn{7}{|c|}{ Panel A: Buy } \\
\hline$-40,-2$ & $\begin{array}{l}-7.18^{\text {क*\%: }} \\
(-11.87)\end{array}$ & $\begin{array}{l}-6.82^{* * * *} \\
(-12.02)\end{array}$ & $\begin{array}{l}-4.58^{\text {अक्स }} \\
(-7.06)\end{array}$ & $\begin{array}{l}-1.76 \\
(-3.03)\end{array}$ & $\begin{array}{c}-1.11 \\
(-1.59)\end{array}$ & 0.00 & $82.06^{3 * \% *}$ \\
\hline$-1,+1$ & $\begin{array}{l}1.41^{* * * *} \\
(8.43)\end{array}$ & $\begin{array}{c}0.97^{* * * *} \\
(6.16)\end{array}$ & $\begin{array}{l}0.83^{\text {***** }} \\
(4.61)\end{array}$ & $\begin{array}{l}0.78^{* * * * *} \\
(4.86)\end{array}$ & $\begin{array}{l}1.01^{* * * *} \\
(5.33)\end{array}$ & 0.38 & 7.17 \\
\hline \multirow[t]{2}{*}{$+2,+40$} & $\begin{array}{l}3.46^{* * * *} \\
(5.72)\end{array}$ & $\begin{array}{l}3.08^{* * * *} \\
(5.42)\end{array}$ & $\begin{array}{l}1.33^{* * *} \\
(2.06)\end{array}$ & $\begin{array}{l}1.95^{* * * *} \\
(3.34)\end{array}$ & $\begin{array}{c}0.79 \\
(1.08)\end{array}$ & 0.00 & $12.43^{* *}$ \\
\hline & \multicolumn{7}{|c|}{ Panel B: Sell } \\
\hline$-40,-2$ & $\begin{array}{l}\text { 3.30 }^{* * * * *} \\
(2.57)\end{array}$ & $\begin{array}{l}4^{4.70} 0^{* * * * *} \\
(4.10)\end{array}$ & $\begin{array}{l}5.64^{* * * * *} \\
(5.40)\end{array}$ & $\begin{array}{l}\text { 6.88 }^{* * * * * *} \\
(6.83)\end{array}$ & $\begin{array}{l}7^{7.33} \\
(6.35)\end{array}$ & 0.01 & 7.72 \\
\hline$-1,+1$ & $\begin{array}{c}-0.07 \\
(-0.19)\end{array}$ & $\begin{array}{c}0.14 \\
(0.46)\end{array}$ & $\begin{array}{c}0.09 \\
(0.33)\end{array}$ & $\begin{array}{c}-0.37 \\
(-1.36)\end{array}$ & $\begin{array}{c}-0.44 \\
(-1.39)\end{array}$ & 0.37 & 2.83 \\
\hline$+2,+40$ & $\begin{array}{c}\text { 0.03 } \\
(\mathbf{0 . 0 2}) \\
\end{array}$ & $\begin{array}{c}0.58 \\
(0.50)\end{array}$ & $\begin{array}{c}0.99 \\
(0.95) \\
\end{array}$ & $\begin{array}{c}-0.60 \\
(-0.61) \\
\end{array}$ & $\begin{array}{c}0.22 \\
(0.19) \\
\end{array}$ & 0.89 & 1.18 \\
\hline
\end{tabular}

The table represents cumulative average abnormal returns around directors' share trading by using the event study methodology. The market model coefficients $\alpha$ and $\beta$ are estimated over days -240 to -41 relative to the event date, with FTSE All Share Index as the proxy for market portfolio. The full sample includes 33,991 directors' trades in 2,664 listed companies, split into 26,268 purchases and 7,723 sells. All results are reported relative to directors' share trading announcement day, i.e., the date of the public announcement of directors' share trading. The market-to-book quintiles were formed 5 days before the announcement dates. If we define $t$ as the event date then we use $t-5$ days' $\mathrm{M} / \mathrm{B}$ ratio to form quintiles based on the M/B ratio. In forming the quintiles we first sort the CARs by year according to Market-to-book ratio. Each year we then sort the CARs in quintiles by market-to-book ratio. Finally, we sort them based in quintiles. In doing so, we have removed the year effect from M/B quintiles. $\mathrm{P}_{\text {high-low }}$ reports the $\mathrm{p}$ value of mean difference test between CAR's from highest $\mathrm{M} / \mathrm{B}$ versus lowest market-to-book quintiles. The last column reports chi-square test for differences in means across market-to-book quintiles. t-statistics are reported in parenthesis. ${ }^{* * * *},{ }^{* *},{ }^{*}$ denote significant at the $0.01,0.05$ and 0.1 level, respectively. 
Table 8. Distribution of Cumulative Abnormal Returns by Size

\begin{tabular}{|c|c|c|c|c|c|c|c|}
\hline \multicolumn{8}{|c|}{ Size Quintiles } \\
\hline & Small & 2 & 3 & 4 & Large & $\mathbf{P}_{\text {small-large }}$ & $\chi^{2}(4)$ \\
\hline & \multicolumn{7}{|c|}{ Panel A: Buy } \\
\hline$-40,-2$ & $\begin{array}{l}-2.25^{* \ldots *} \\
(-2.69)\end{array}$ & $\begin{array}{c}-4.89^{\text {*F*3\% }} \\
(-7.53)\end{array}$ & $\begin{array}{l}-7.79^{3 * \% *} \\
(-12.42)\end{array}$ & $\begin{array}{l}-3.76^{\text {***\% }} \\
(-6.75)\end{array}$ & $\begin{array}{l}-2.93^{\text {*6\%k }} \\
(-4.87)\end{array}$ & 0.53 & $43.79^{* * \% *}$ \\
\hline$-1,+1$ & $\begin{array}{l}3.02^{* * * *} \\
(13.03)\end{array}$ & $\begin{array}{c}1.22^{* * * *} \\
(6.77)\end{array}$ & $\begin{array}{l}0.76^{* * * *} \\
(4.37)\end{array}$ & $\begin{array}{c}0.15 \\
(1.03)\end{array}$ & $\begin{array}{c}-0.12 \\
(-0.70)\end{array}$ & 0.00 & $156.47^{* * *}$ \\
\hline \multirow[t]{2}{*}{$+2,+40$} & $\begin{array}{c}2.95^{* * * *} \\
(3.52)\end{array}$ & $\begin{array}{l}3.47^{* * * *} \\
(\mathbf{5 . 3 4})\end{array}$ & $\begin{array}{l}2.36 \\
(3.76)\end{array}$ & $\begin{array}{c}0.94^{*} \\
(1.68)\end{array}$ & $\begin{array}{c}0.48 \\
(0.81)\end{array}$ & 0.00 & $57.33^{* * *}$ \\
\hline & \multicolumn{7}{|c|}{ Panel B: Sell } \\
\hline$-40,-2$ & $\begin{array}{l}4.62^{* * * * *} \\
(3.40)\end{array}$ & $\begin{array}{l}5^{5.65} \\
(6.14)\end{array}$ & $\begin{array}{l}6.67^{* * * * * *} \\
(6.25)\end{array}$ & $\begin{array}{l}5.58^{* * * * *} \\
(4.54)\end{array}$ & $\begin{array}{l}5.45^{* * * *} \\
(5.76)\end{array}$ & 0.58 & 1.55 \\
\hline$-1,+1$ & $\begin{array}{c}0.20 \\
(0.53)\end{array}$ & $\begin{array}{c}-0.44 \\
(-1.73)\end{array}$ & $\begin{array}{c}-0.28 \\
(-0.95)\end{array}$ & $\begin{array}{c}0.28 \\
(0.82)\end{array}$ & $\begin{array}{c}-0.40 \\
(1.54)\end{array}$ & 0.27 & 5.02 \\
\hline$+2,+40$ & $\begin{array}{l}3.00^{* * *} \\
(2.21)\end{array}$ & $\begin{array}{c}-0.83 \\
(-0.89)\end{array}$ & $\begin{array}{c}-0.08 \\
(-0.08)\end{array}$ & $\begin{array}{c}-0.46 \\
(-0.38)\end{array}$ & $\begin{array}{c}-0.42 \\
(-0.45)\end{array}$ & 0.00 & 6.39 \\
\hline
\end{tabular}

The above table represents cumulative average abnormal returns around directors' share trading by using event study methodology. The market model coefficients $\alpha$ and $\beta$ are estimated over days -220 to -41 relative to the event, with FTSE All Share Index as the proxy for market portfolio. The full sample includes 33,991 directors' trades in 2,664 listed companies, split into 26,268 purchases and 7,723 sells. All results are reported relative to directors' share trading announcement day, i.e., the date of the public announcement of directors' share trading. The size quintiles were formed 5 days before the announcement dates. If we define $t$ as event date then we use t-5 days' size to form quintiles based on the size. In forming the quintiles CARs are first sorted by year according to size. Each year CARs are then sorted in quintiles by size. Finally, they are sorted in quintiles. By doing so, the year effect from Market-to-book quintiles has been removed. $\mathrm{P}_{\text {small-large }}$ reports the $\mathrm{p}$ value of mean difference test between CARs from highest market-to-book versus lowest market-to-book quintiles. The last column reports chi-square test for differences in means across size quintiles. T-statistics are reported in parenthesis. ${ }^{* * *},{ }^{* *},{ }^{*}$ denote significant at the $0.01,0.05$ and 0.1 level, respectively. 
Table 9. Distribution of Abnormal Returns of Buy Trades by Size \& M/B

\begin{tabular}{|c|c|c|c|c|c|}
\hline & Low M/B & 2 & 3 & 4 & High M/B \\
\hline & \multicolumn{5}{|c|}{ Pre-trade Returns $(-40,-2)$} \\
\hline Small & $\begin{array}{c}-4.65^{\text {**** }} \\
(-3.62)\end{array}$ & $\begin{array}{c}-4.83^{* * *} \\
(-3.52)\end{array}$ & $\begin{array}{l}-3.62^{* *} \\
(-2.34)\end{array}$ & $\begin{array}{l}-3.40^{* *} \\
(-2.04)\end{array}$ & $\begin{array}{c}-0.32 \\
(-0.15)\end{array}$ \\
\hline 2 & $\begin{array}{c}-12.82^{* * * *} \\
(-5.56)\end{array}$ & $\begin{array}{c}-13.32^{* * * *} \\
(-6.30)\end{array}$ & $\begin{array}{l}-6.44^{* * * *} \\
(-3.63)\end{array}$ & $\begin{array}{l}-5.02^{* *} \\
(-2.13)\end{array}$ & $\begin{array}{c}0.29 \\
(0.14)\end{array}$ \\
\hline 3 & $\begin{array}{l}-7.62^{* * *} \\
(-4.08)\end{array}$ & $\begin{array}{c}-4.82^{* * * *} \\
(-2.73)\end{array}$ & $\begin{array}{l}-6.87^{* * * *} \\
(-3.19)\end{array}$ & $\begin{array}{l}-7.18^{* * * *} \\
(-3.68)\end{array}$ & $\begin{array}{c}-0.73 \\
(-0.36)\end{array}$ \\
\hline 4 & $\begin{array}{l}-9.09^{* * * *} \\
(-4.57)\end{array}$ & $\begin{array}{c}-5.75^{* * * *} \\
(-2.55)\end{array}$ & $\begin{array}{l}-1.95 \\
(-0.86)\end{array}$ & $\begin{array}{l}-2.26 \\
(-0.96)\end{array}$ & $\begin{array}{l}-2.17 \\
(-1.32)\end{array}$ \\
\hline \multirow[t]{2}{*}{ Big } & $\begin{array}{l}-1.68 \\
(-0.25)\end{array}$ & $\begin{array}{c}-14.91^{* * * *} \\
(-3.54) \\
\end{array}$ & $\begin{array}{c}-3.64 \\
(-1.53) \\
\end{array}$ & $\begin{array}{c}-1.05 \\
(-0.62) \\
\end{array}$ & $\begin{array}{c}-2.06 \\
(-1.09) \\
\end{array}$ \\
\hline & \multicolumn{5}{|c|}{ Event day Returns $(-1,+1)$} \\
\hline Small & $\begin{array}{l}1.92^{* * *} \\
(4.80)\end{array}$ & $\begin{array}{l}2.35^{* * *} \\
(5.48)\end{array}$ & $\begin{array}{l}2.35^{* * * *} \\
(4.87)\end{array}$ & $\begin{array}{l}1.90^{* * * *} \\
(4.87)\end{array}$ & $\begin{array}{l}4.13^{* * * *} \\
(6.04)\end{array}$ \\
\hline 2 & $\begin{array}{l}1.38^{* * *} \\
(1.91)\end{array}$ & $\begin{array}{c}0.88 \\
(1.33)\end{array}$ & $\begin{array}{c}0.65 \\
(1.18)\end{array}$ & $\begin{array}{l}1.20^{*} \\
(1.64)\end{array}$ & $\begin{array}{l}2.54^{* * * *} \\
(3.80)\end{array}$ \\
\hline 3 & $\begin{array}{l}1.10^{*} \\
(1.87)\end{array}$ & $\begin{array}{c}0.52 \\
(0.94)\end{array}$ & $\begin{array}{c}-0.49 \\
(-0.73)\end{array}$ & $\begin{array}{c}0.20 \\
(0.32)\end{array}$ & $\begin{array}{c}0.45 \\
(0.72)\end{array}$ \\
\hline 4 & $\begin{array}{c}0.43 \\
(0.69)\end{array}$ & $\begin{array}{l}-1.68^{* *} \\
(-2.38)\end{array}$ & $\begin{array}{c}0.33 \\
(0.47)\end{array}$ & $\begin{array}{c}0.44 \\
(0.59)\end{array}$ & $\begin{array}{c}0.22 \\
(0.43)\end{array}$ \\
\hline \multirow[t]{2}{*}{ Big } & $\begin{array}{c}3.16 \\
(1.53) \\
\end{array}$ & $\begin{array}{c}0.09 \\
(0.07) \\
\end{array}$ & $\begin{array}{c}-0.31 \\
(-0.41) \\
\end{array}$ & $\begin{array}{c}0.06 \\
(0.12) \\
\end{array}$ & $\begin{array}{c}-0.58 \\
(-0.98) \\
\end{array}$ \\
\hline & \multicolumn{5}{|c|}{ Post-trade Returns $(+2,+40)$} \\
\hline Small & $\begin{array}{l}4.66^{* * *} \\
(5.11)\end{array}$ & $\begin{array}{l}2.49^{* *} \\
(2.55)\end{array}$ & $\begin{array}{c}1.98^{*} \\
(1.80)\end{array}$ & $\begin{array}{l}2.07^{*} \\
(1.74)\end{array}$ & $\begin{array}{l}3.12^{* *} \\
(2.01)\end{array}$ \\
\hline 2 & $\begin{array}{l}5.23^{* * * *} \\
(3.19)\end{array}$ & $\begin{array}{l}7.07^{* * * *} \\
(4.70)\end{array}$ & $\begin{array}{c}0.67 \\
(0.53)\end{array}$ & $\begin{array}{c}1.80 \\
(1.07)\end{array}$ & $\begin{array}{c}1.64 \\
(1.08)\end{array}$ \\
\hline 3 & $\begin{array}{l}3.58^{* * *} \\
(2.69)\end{array}$ & $\begin{array}{c}1.49 \\
(1.18)\end{array}$ & $\begin{array}{c}2.05 \\
(1.34)\end{array}$ & $\begin{array}{c}3.45 \\
(2.49)\end{array}$ & $\begin{array}{l}-1.73 \\
(-1.22)\end{array}$ \\
\hline 4 & $\begin{array}{l}-0.66 \\
(-0.47)\end{array}$ & $\begin{array}{c}1.57 \\
(0.98)\end{array}$ & $\begin{array}{c}1.07 \\
(0.66)\end{array}$ & $\begin{array}{c}1.60 \\
(0.96)\end{array}$ & $\begin{array}{c}1.56 \\
(1.33)\end{array}$ \\
\hline Big & $\begin{array}{c}1.34 \\
(0.29)\end{array}$ & $\begin{array}{l}7.13^{* *} \\
(2.38)\end{array}$ & $\begin{array}{c}0.43 \\
(0.25)\end{array}$ & $\begin{array}{c}0.96 \\
(0.79)\end{array}$ & $\begin{array}{c}-0.31 \\
(-0.23)\end{array}$ \\
\hline
\end{tabular}

The above table represents cumulative average abnormal returns around directors' share trading by using event study methodology. The market model coefficients $\alpha$ and $\beta$ are estimated over days -220 to -41 relative to the event, with FTSE All Share Index as the proxy for market portfolio. The full sample includes 33,991 directors' trades in 2,664 listed companies, split into 26,268 purchases and 7,723 sells. All results are reported relative to directors' share trading announcement day, i.e., the date of the public announcement of directors' share trading. The M/B and size quintiles were formed 5 days before the announcement dates. If we define $t$ as event date, then we use t-5 days' $\mathrm{M} / \mathrm{B}$ and size to form quintiles based on $\mathrm{M} / \mathrm{B}$ and size. In forming the quintiles the CARs were first by year according to M/B and size. Each year then the CARs were sorted in quintiles first by M/B and then by size. By doing so, the year effect have been removed from quintiles. T-statistics are reported in parenthesis. ${ }^{* * *},{ }^{* *},{ }^{*}$ denote significant at the $0.01,0.05$ and 0.1 level, respectively. 
Table 10. Distribution of Abnormal Returns of Sell Trades by M/B and Size

\begin{tabular}{|c|c|c|c|c|c|}
\hline & Low M/B & 2 & 3 & 4 & High $\mathrm{M} / \mathrm{B}$ \\
\hline & \multicolumn{5}{|c|}{ Pre-trade Returns $(-40,-2)$} \\
\hline Small & $\begin{array}{l}3.83^{* *} \\
(2.51)\end{array}$ & $\begin{array}{c}2.91 \\
(1.05)\end{array}$ & $\begin{array}{c}4.01 \\
(1.60)\end{array}$ & $\begin{array}{c}2.59 \\
(1.00)\end{array}$ & $\begin{array}{c}0.11 \\
(0.02)\end{array}$ \\
\hline 2 & $\begin{array}{l}7.67^{* * * *} \\
(4.94)\end{array}$ & $\begin{array}{c}1.21 \\
(0.56)\end{array}$ & $\begin{array}{l}10.60^{* * *} \\
(2.40)\end{array}$ & $\begin{array}{c}1.39 \\
(0.47)\end{array}$ & $\begin{array}{c}0.48 \\
(0.14)\end{array}$ \\
\hline 3 & $\begin{array}{l}3.82^{* * *} \\
(2.02)\end{array}$ & $\begin{array}{c}3.84 \\
(1.55)\end{array}$ & $\begin{array}{c}10.40^{* * * * *} \\
(3.10)\end{array}$ & $\begin{array}{l}5.32^{* *} \\
(2.18)\end{array}$ & $\begin{array}{l}8.03^{* *} \\
(3.43)\end{array}$ \\
\hline 4 & $\begin{array}{c}10.66^{* * * *} \\
(3.99)\end{array}$ & $\begin{array}{l}7.44^{* * * *} \\
(3.49)\end{array}$ & $\begin{array}{c}3.85 \\
(1.20)\end{array}$ & $\begin{array}{l}7.56^{* * * *} \\
(3.90)\end{array}$ & $\begin{array}{c}3.20 \\
(1.22)\end{array}$ \\
\hline \multirow[t]{2}{*}{ Big } & $\begin{array}{c}4.23 \\
(1.42) \\
\end{array}$ & $\begin{array}{l}9.52^{* * * *} \\
(3.95) \\
\end{array}$ & $\begin{array}{l}7.97^{* * * *} \\
(4.52)\end{array}$ & $\begin{array}{l}7.22^{* * * * *} \\
(3.38)\end{array}$ & $\begin{array}{c}4.17 \\
(1.06) \\
\end{array}$ \\
\hline & \multicolumn{5}{|c|}{ Event day Returns $(-1,+1)$} \\
\hline Small & $\begin{array}{l}-0.45 \\
(-0.94)\end{array}$ & $\begin{array}{c}0.50 \\
(0.57)\end{array}$ & $\begin{array}{c}-0.08 \\
(-0.10)\end{array}$ & $\begin{array}{c}0.80 \\
(0.98)\end{array}$ & $\begin{array}{l}-1.32 \\
(0.90)\end{array}$ \\
\hline 2 & $\begin{array}{c}0.27 \\
(0.56)\end{array}$ & $\begin{array}{c}0.14 \\
(0.21)\end{array}$ & $\begin{array}{l}-1.90 \\
(-1.37)\end{array}$ & $\begin{array}{c}0.51 \\
(0.55)\end{array}$ & $\begin{array}{c}0.31 \\
(0.29)\end{array}$ \\
\hline 3 & $\begin{array}{c}0.79 \\
(1.33)\end{array}$ & $\begin{array}{c}-0.75 \\
(-0.97)\end{array}$ & $\begin{array}{c}0.04 \\
(0.03)\end{array}$ & $\begin{array}{c}0.63 \\
(0.83)\end{array}$ & $\begin{array}{c}-0.67 \\
(-0.91)\end{array}$ \\
\hline 4 & $\begin{array}{l}-1.03 \\
(-1.23)\end{array}$ & $\begin{array}{c}-0.61 \\
(-0.92)\end{array}$ & $\begin{array}{c}0.03 \\
(0.03)\end{array}$ & $\begin{array}{c}0.01 \\
(0.01)\end{array}$ & $\begin{array}{c}-0.37 \\
(-0.44)\end{array}$ \\
\hline \multirow[t]{2}{*}{ Big } & $\begin{array}{c}0.16 \\
(0.17)\end{array}$ & $\begin{array}{c}-0.33 \\
(-0.44)\end{array}$ & $\begin{array}{c}-0.43 \\
(-0.77)\end{array}$ & $\begin{array}{c}-0.80 \\
(-1.19)\end{array}$ & $\begin{array}{c}-0.66 \\
(-0.54)\end{array}$ \\
\hline & \multicolumn{5}{|c|}{ Post-trade Returns $(+2,+40)$} \\
\hline Small & $\begin{array}{c}1.80 \\
(1.39)\end{array}$ & $\begin{array}{c}-0.30 \\
(-0.13)\end{array}$ & $\begin{array}{c}-0.83 \\
(-0.39)\end{array}$ & $\begin{array}{l}-4.77^{* * *} \\
(-2.16)\end{array}$ & $\begin{array}{c}4.25 \\
(0.90)\end{array}$ \\
\hline 2 & $\begin{array}{c}1.90 \\
(1.44)\end{array}$ & $\begin{array}{c}1.28 \\
(0.69)\end{array}$ & $\begin{array}{l}-1.51 \\
(-0.40)\end{array}$ & $\begin{array}{c}-2.43 \\
(-0.96)\end{array}$ & $\begin{array}{c}-2.19 \\
(-0.77)\end{array}$ \\
\hline 3 & $\begin{array}{l}-1.02 \\
(-0.63)\end{array}$ & $\begin{array}{c}2.04 \\
(0.97)\end{array}$ & $\begin{array}{c}-0.28 \\
(-0.10)\end{array}$ & $\begin{array}{c}3.54^{*} \\
(1.70)\end{array}$ & $\begin{array}{c}1.41 \\
(0.71)\end{array}$ \\
\hline 4 & $\begin{array}{l}-1.76 \\
(-0.77)\end{array}$ & $\begin{array}{l}-1.04 \\
(-0.57)\end{array}$ & $\begin{array}{c}2.40 \\
(0.88)\end{array}$ & $\begin{array}{c}-0.43 \\
(-0.26)\end{array}$ & $\begin{array}{l}-1.20 \\
(-0.54)\end{array}$ \\
\hline Big & $\begin{array}{l}5.19^{* *} \\
(2.04)\end{array}$ & $\begin{array}{c}-1.07 \\
(-0.52) \\
\end{array}$ & $\begin{array}{c}-2.31 \\
(-1.54) \\
\end{array}$ & $\begin{array}{c}1.43 \\
(0.78) \\
\end{array}$ & $\begin{array}{c}3.58 \\
(1.08) \\
\end{array}$ \\
\hline
\end{tabular}

The above table represents cumulative average abnormal returns around directors' share trading by using event study methodology. The market model coefficients $\alpha$ and $\beta$ are estimated over days -220 to -41 relative to the event, with FTSE All Share Index as the proxy for market portfolio. The full sample includes 33,991 directors' trades in 2,664 listed companies, split into 26,268 purchases and 7,723 sells. All results are reported relative to directors' share trading announcement day, i.e., the date of the public announcement of directors' share trading. The $\mathrm{M} / \mathrm{B}$ and size quintiles were formed 5 days before the announcement dates. If we define $t$ as event date, then we use t-5 days' $\mathrm{M} / \mathrm{B}$ and size to form quintiles based on $\mathrm{M} / \mathrm{B}$ and size. In forming the quintiles the CARs were first by year according to M/B and size. Each year then the CARs were sorted in quintiles first by M/B and then by size. By doing so, the year effect have been removed from quintiles. T-statistics are reported in parenthesis. ${ }^{* * * *},{ }^{* *},{ }^{*}$ denote significant at the $0.01,0.05$ and 0.1 level, respectively. 
Table 11. Distribution of CARs by Stock and Market Volatility

\begin{tabular}{|c|c|c|c|c|c|c|c|}
\hline \multicolumn{8}{|c|}{ Stock volatility Quintiles } \\
\hline & Low & 2 & $\mathbf{3}$ & 4 & High & $\mathbf{P}_{\text {High- }}$ & $\chi^{2}(4)$ \\
\hline & & & & & & Low & \\
\hline & \multicolumn{7}{|c|}{ Panel A: Buy } \\
\hline \multirow[t]{2}{*}{$-40,-2$} & $-1.32^{* * *}$ & $-3.53^{* * *}$ & $-5.06^{* * * *}$ & $-3.50^{* * * * *}$ & $-8.20^{* * * *}$ & 0.000 & $30.15^{* * *}$ \\
\hline & -5.11 & -13.10 & -16.41 & -11.07 & -12.80 & & \\
\hline \multirow[t]{2}{*}{$-1,+1$} & $0.75^{* * *}$ & $0.66^{* * *}$ & $0.85^{* * *}$ & $0.45^{\text {**** }}$ & $2.35^{* * *}$ & 0.000 & $15.65^{* *}$ \\
\hline & 10.87 & 7.09 & 8.73 & 3.83 & 12.36 & & \\
\hline \multirow[t]{3}{*}{$+2,+40$} & $2.16^{* * *}$ & $1.63^{* * * *}$ & $1.01^{* * * *}$ & $2.23^{\text {**** }}$ & $3.19^{* * * *}$ & 0.000 & 5.3 \\
\hline & 10.55 & 6.88 & 3.78 & 8.56 & 8.15 & & \\
\hline & \multicolumn{7}{|c|}{ Panel B: Sell } \\
\hline \multirow[t]{2}{*}{$-40,-2$} & $5.66^{* * * *}$ & $4.66^{* * * *}$ & $3.77^{* * * *}$ & $4.26^{* * * *}$ & $9.59^{* * * *}$ & 0.024 & $12.95^{*}$ \\
\hline & 6.12 & 5.30 & 4.38 & 4.22 & 6.52 & & \\
\hline \multirow[t]{2}{*}{$-1,+1$} & 0.14 & $-0.45^{*}$ & -0.22 & -0.49 & 0.36 & 0.692 & 3.44 \\
\hline & 0.81 & -1.78 & -0.76 & -1.55 & 0.69 & & \\
\hline \multirow[t]{2}{*}{$+2,+40$} & 0.14 & -0.20 & 1.09 & -0.95 & 1.15 & 0.450 & 3.36 \\
\hline & 0.18 & -0.29 & 1.29 & -0.89 & 1.04 & & \\
\hline \multicolumn{8}{|c|}{ Market volatility Quintiles } \\
\hline \multicolumn{8}{|c|}{ Panel C: Buy } \\
\hline \multirow[t]{2}{*}{$-40,-2$} & $-7.49^{* * * *}$ & $-4.93^{* * *}$ & $-2.69^{* * * *}$ & $-1.16^{* * * * *}$ & $-5.36^{* * * *}$ & 0.092 & $42.90^{* * * *}$ \\
\hline & -20.71 & -11.08 & -7.27 & -3.95 & -12.18 & & \\
\hline \multirow[t]{2}{*}{$-1,+1$} & $0.76^{* * *}$ & $0.79^{* * * *}$ & $1.06^{* * * *}$ & $1.02^{* * * *}$ & $1.43^{* * * *}$ & 0.081 & 3.63 \\
\hline & 7.16 & 6.54 & 8.89 & 8.52 & 10.38 & & \\
\hline \multirow[t]{2}{*}{$+2,+40$} & $0.97^{* * *}$ & $1.44^{* * * *}$ & $0.45^{*}$ & $3.86^{\text {***** }}$ & $3.46^{* * * *}$ & 0.000 & $29.80^{* * * *}$ \\
\hline & 3.23 & 4.17 & 1.78 & 17.16 & 13.79 & & \\
\hline \multicolumn{8}{|c|}{ Panel D: Sell } \\
\hline \multirow[t]{2}{*}{$-40,-2$} & $7.46^{* * *}$ & $6.29^{* * * *}$ & $5.86^{* * * *}$ & $5.07^{* * * *}$ & $3.30^{* * * *}$ & 0.018 & $8.78^{*}$ \\
\hline & 4.94 & 6.88 & 5.75 & 6.05 & 3.77 & & \\
\hline \multirow[t]{2}{*}{$-1,+1$} & -0.59 & 0.24 & -0.17 & 0.15 & -0.27 & 0.496 & 3.44 \\
\hline & -1.61 & 0.66 & -0.63 & 0.42 & -0.91 & & \\
\hline \multirow[t]{2}{*}{$+2,+40$} & -1.62 & -1.66 & 0.41 & $2.21^{* * * *}$ & $1.89^{* * * *}$ & 0.007 & $16.42^{* *}$ \\
\hline & -1.45 & -1.51 & 0.52 & 3.02 & 2.93 & & \\
\hline
\end{tabular}

The above table represents cumulative average abnormal returns around directors' share trading by using event study methodology. The market model coefficients $\alpha$ and $\beta$ are estimated over days -220 to -41 relative to the event, with FTSE All Share Index as the proxy for market portfolio. The full sample includes 33,991 directors' trades in 2,664 listed companies, split into 26,268 purchases and 7,723 sells. All results are reported relative to directors' share trading announcement day, i.e., the date of the public announcement of directors' share trading. Stock Volatility is standard deviation of stock returns over -240 to- 41 days and Market Volatility is standard deviation of market returns over -240 to-41 days. In forming stock volatility quintiles, CARs are sorted by stock volatility. In forming market volatility quintiles, CARs are sorted by market volatility. $\mathrm{P}_{\text {low-high }}$ reports the $\mathrm{p}$ value of mean difference test between CARs from highest volatility versus lowest volatility quintiles. The last column reports chi-square test for differences in means across size quintiles. T-statistics are reported under the CARs. ${ }^{* * *},{ }^{* *},{ }^{*}$ denote significant at the $0.01,0.05$ and 0.1 level, respectively. 
Table 12. OLS Results on CARs

\begin{tabular}{|c|c|c|c|c|c|c|c|c|}
\hline & Panel A: & Buy Trades & & & Panel B: & Sell Trades & & \\
\hline & $\mathrm{CAR}_{-1,+1}$ & & $\mathbf{C A R}_{+2,+40}$ & & CAR $_{-1,+1}$ & & $\mathrm{CAR}_{+2,+40}$ & \\
\hline & Model 1 & Model 2 & Model 1 & Model 2 & Model 1 & Model 2 & Model 1 & Model 2 \\
\hline \multirow[t]{2}{*}{ Intercept } & 0.003 & -0.005 & 0.003 & $-0.085^{* * *}$ & 0.003 & 0.002 & $-0.052 *$ & $-0.048^{*}$ \\
\hline & (0.79) & $(-0.37)$ & (0.11) & $(-2.39)$ & $(0.25)$ & $(0.29)$ & $(-1.76)$ & $(-1.89)$ \\
\hline \multirow[t]{2}{*}{ Ln (Size) } & $-0.003^{* * * *}$ & $-0.003^{* * * *}$ & $-0.004^{* * *}$ & $-0.004^{* *}$ & -0.005 & -0.006 & $-0.004^{* * * *}$ & $-0.004^{* * *}$ \\
\hline & $(-5.27)$ & $(-5.09)$ & $(-2.23)$ & $(-2.23)$ & $(-0.84)$ & $(-0.74)$ & $(-2.92)$ & $(-2.25)$ \\
\hline \multirow[t]{2}{*}{ Market to book } & $-0.001^{*}$ & $-0.003^{*}$ & -0.007 & $-0.007^{*}$ & -0.001 & -0.003 & $0.002^{*}$ & $0.001^{*}$ \\
\hline & $(-1.94)$ & $(-2.36)$ & $(-1.61)$ & $-(1.80)$ & $(-0.57)$ & $(-0.64)$ & (1.74) & (1.65) \\
\hline \multirow[t]{2}{*}{ Stock Volatility } & $0.518^{* * * * *}$ & $0.510^{* * * * *}$ & $0.840^{* * * * *}$ & $0.789^{* * * * *}$ & 0.075 & 0.073 & 0.553 & 0.353 \\
\hline & $(4.80)$ & $(3.13)$ & $(2.52)$ & $(2.36)$ & $(0.25)$ & $(0.31)$ & $(0.54)$ & $(0.46)$ \\
\hline \multirow[t]{2}{*}{ Market Volatility } & 0.353 & 0.838 & $0.29^{* * * *}$ & $0.523^{* * * *}$ & 0.414 & 0.264 & $0.852^{* * * *}$ & $0.912^{* * * *}$ \\
\hline & (0.60) & (1.06) & (3.17) & $(5.42)$ & $(0.45)$ & $(0.41)$ & $(4.54)$ & $(4.52)$ \\
\hline \multirow[t]{2}{*}{ BB Dummy } & 0.001 & -- & 0.008 & -- & 0.003 & -- & 0.002 & -- \\
\hline & $(0.44)$ & & (1.25) & & $(0.57)$ & & $(0.52)$ & \\
\hline Industry Dummy & Yes & Yes & Yes & Yes & Yes & Yes & Yes & Yes \\
\hline Year Dummy & -- & Yes & -- & Yes & -- & Yes & -- & Yes \\
\hline $\mathbf{R}_{\text {adjusted }}^{2}$ & $\mathbf{0 . 0 5 3}$ & 0.053 & 0.042 & $\mathbf{0 . 0 3 3}$ & 0.035 & 0.020 & 0.022 & 0.022 \\
\hline F (Probability) & $5.72(0.00)$ & $5.40(0.00)$ & 3.53(0.00) & $3.73(0.00)$ & $0.46(0.81)$ & $0.38(0.85)$ & $5.06(0.00)$ & $4.59(0.00)$ \\
\hline
\end{tabular}

The above table reports the regression results using the following model.

$$
C A R_{j}=\alpha+\beta_{1} \operatorname{Ln}(\text { Size })_{j}+\beta_{2} M / B_{j}+\beta_{3}{\text { Stock } \text { Vol }_{j}+\beta_{4} \text { MktVol }_{j}+\kappa B B D u m}+\gamma \text { Year }+\theta \text { Industry }
$$

where, $C A R_{j, t}$ is the CAR of insider trades for the $(-1,+1)$ and $(+2,+40)$ event windows. Model 1 is the model with bull (bear) dummy and industry dummy and model 2 is model with year dummy and industry dummy. $L n($ size $)$ is the log of size of the company measured as market value of equity, $M / B$ is the market-to-book ratio.. Stock Vol is volatility of stock measured by standard deviation over 180 days prior to the event and Mkt Vol is volatility of market measured by standard deviation over the same estimation period. The BB dummy is one if the trade is from bull period (January 1999 to March 2000 and January 2004 to December 2007) and zero otherwise. White heteroscedasticity consistent t-statistics is reported in parenthesis. The last row reports F-statistics with p-values in the parenthesis next to it. $* * *, * *$ and $*$ indicates significant at $1 \%, 5 \%$ and $10 \%$ levels, respectively. 
Figure 1. Monthly NPR and Market Returns

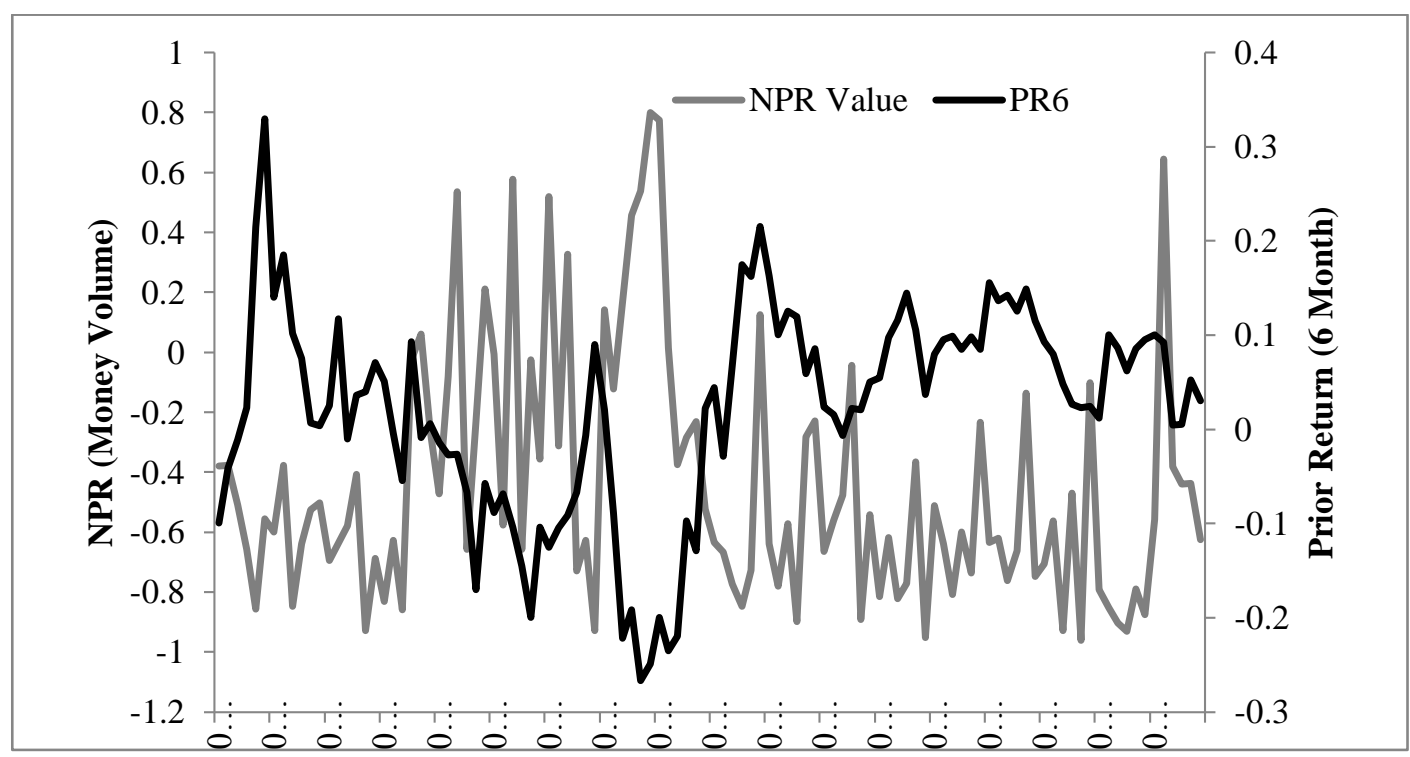

This figure represents a time series of net purchase ratio (NPR Value) and 6-month prior return (PR6) for each month from January 1999 to December 2007. For each month, we calculate the total Pound sterling volume (and the total numbers of) insider purchases and sells. We then calculate the NPR by dividing the net aggregate value of insider purchases by the total aggregate value of insider transactions. Prior Returns (PR6) represents the FTSE All Share Index returns over the 6 months before the trade.

Figure 2. Aggregate Insider Trading and Bull (Bear) Market

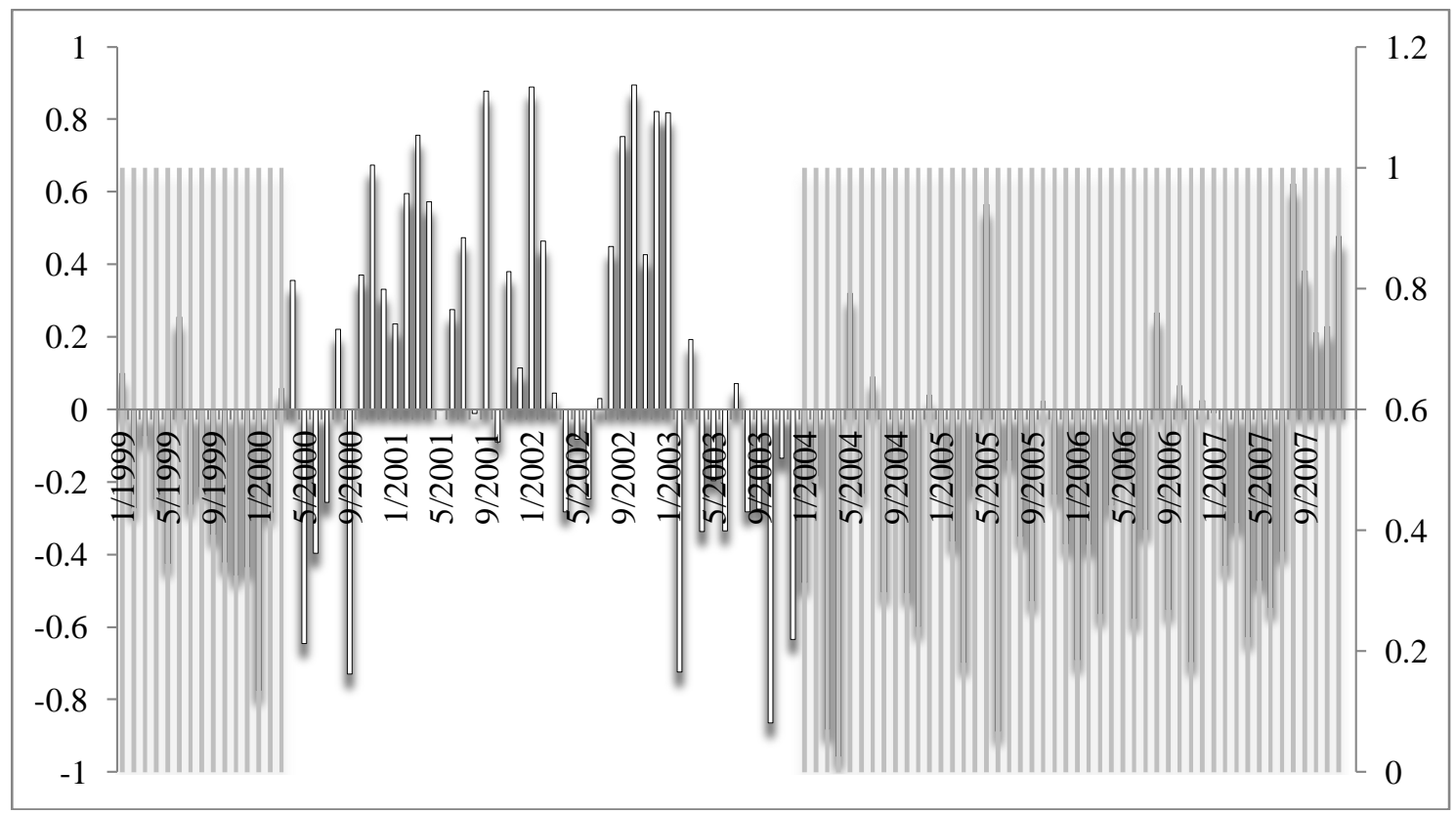

This figure represents a time series of net purchase ratio for each month from January 1999 to December 2007. The shaded region is the bull market and contains two periods (January 1999 to March 2000 and January 2004 to December 2007). For each month, we calculate the total numbers of (and the total Pound Sterling volume) insider purchases and sells. We then calculate the NPR by dividing the net aggregate number of insider purchases by the total aggregate number of insider transactions. 
Figure 3. Abnormal returns of insider purchases by growth quintiles

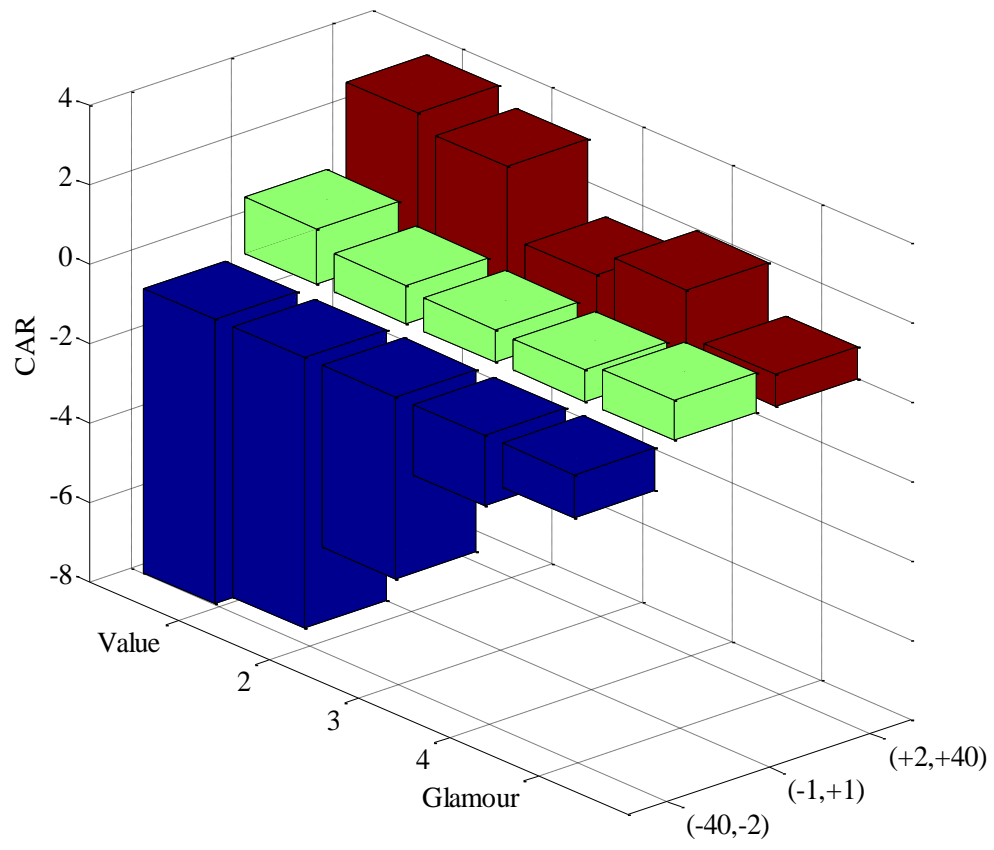

Figure 4. Abnormal returns of insider sells by growth quintiles

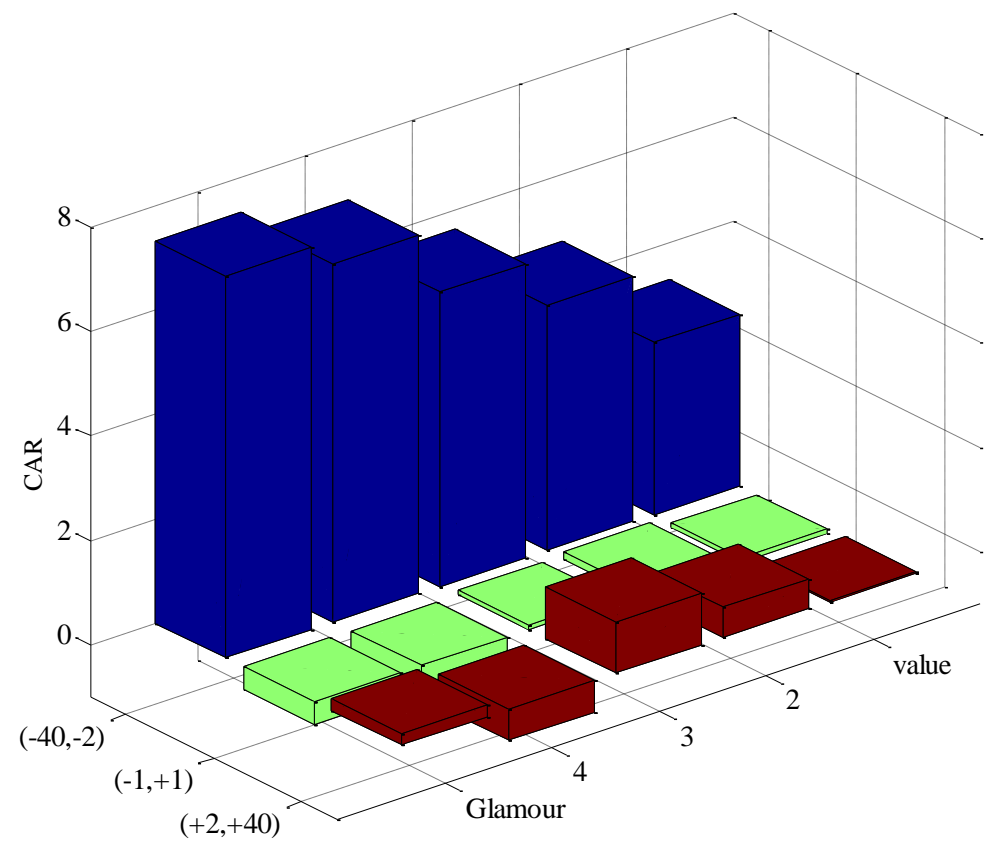


Figure 5.Abnormal returns of insider purchases by size quintiles

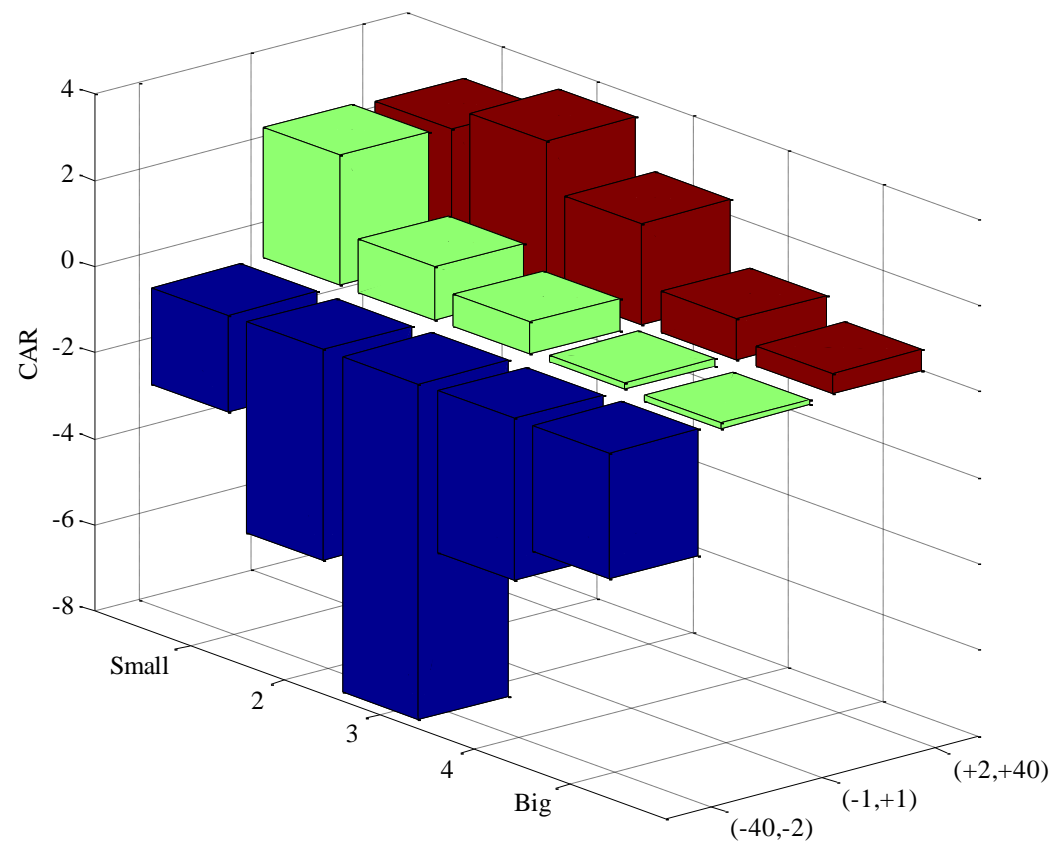

Figure 6. Abnormal returns of insider sells by size quintiles

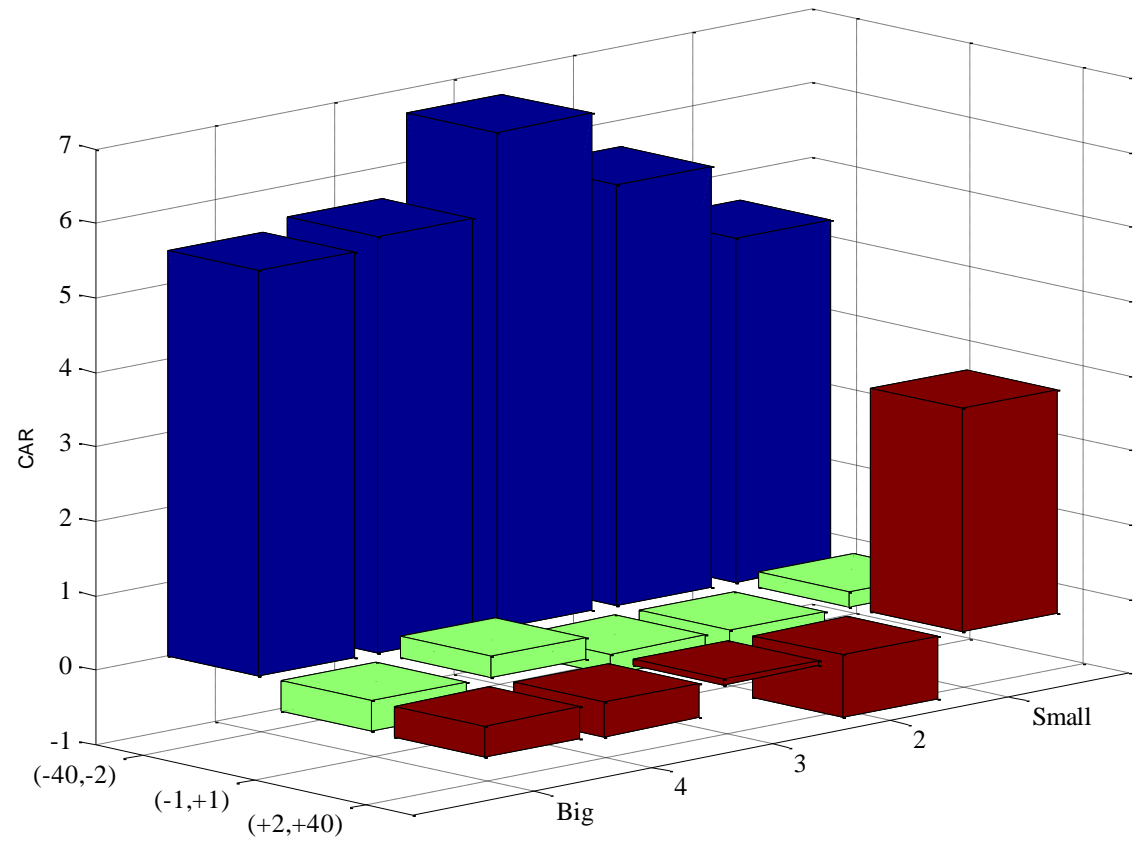


${ }^{1}$ All the studies except Fahlenbrach and Stultz (2011) show that insider have superior knowledge and better timing ability.

${ }^{2}$ For a detailed discussion on the differences in regulations and reporting periods, please see Fidrmuc et al (2006) and a discussion on trading bans see Hillier and Marshall (2002).

${ }^{3}$ Though Gregory et al (forthcoming) analyse value/glamour strategies, their focus is on long run returns. In this paper we focus on short run returns.

${ }_{4}$ Though these bull and bear markets are very well known in financial markets, to avoid any subjectivity, we calculate monthly market returns and confirm that market returns remain negative during the bear period and market returns remain positive during the bull period.

${ }^{5}$ In unreported regressions, we use 6, 12 and 18 months prior returns and the results are qualitatively similar.

${ }^{6}$ For example, Fidrmuc et al (2006) did not find any significant returns outside the $(-20,+20)$ window.

${ }^{7}$ Pope et al. (1990) and Gregory et al. (1994) find puzzling results as market model CARs are negative for buy, and the returns are substantial. The results change dramatically when they adjust for size as the CAR's become positive for buys and negative for sells in the post event window.

${ }^{8}$ We document that returns are larger when market and stock volatility is larger. This could simply be an artefact of using CARs, which are flawed for anything other than very short windows. So, one might argue that a positive relationship between CARs and returns are unsurprising given the well-known problems of positive bias in CARs (Kothari and Werner, 1997). So, we repeat the analysis using BHARs (unreported) and the results remain qualitatively similar. Hence, we conclude that insiders are more knowledgeable in volatile stocks. 